\title{
How Do Very Open Economies Absorb Large Immigration Flows? Recent Evidence from Spanish Regions
}

\author{
Libertad González \\ Universitat Pompeu Fabra and IAE (CSIC) \\ Francesc Ortega \\ Universitat Pompeu Fabra and IAE (CSIC)
}

December 2007

\begin{abstract}
In recent years, Spain has received unprecedented immigration flows. Between 2001 and 2006 the fraction of the population born abroad more than doubled, increasing from $4.8 \%$ to $10.8 \%$. For Spanish provinces with above-median inflows (relative to population), immigration increased the high school dropout population by $24 \%$, while only increasing the number of college graduates by $11 \%$. We study the different channels by which regional labor markets have absorbed the large increase in the relative supply of low educated (foreign-born) workers. We identify the exogenous supply shock using historical immigrant settlement patterns by country of origin. Using data from the Labor Force Survey and the decennial Census, we find a large expansion of employment in high immigration regions. Specifically, most industries in high-immigration regions experienced a large increase in the share of low-education employment. We do not find an effect on regions' sectoral specialization. Overall, and perhaps surprisingly, Spanish regions have absorbed immigration flows in the same fashion as US local economies.
\end{abstract}

JEL Codes: J2, F1, O3.

Keywords: Immigration, Open Economies, Rybcszynski, Instrumental Variables.

We thank Paula Bustos, Jesús Fernández-Huertas, Albrecht Glitz, Thijs van Rens, Sara de la Rica, Marcos Vera, and participants in the seminars at Bocconi, La Laguna, Pompeu Fabra, and Vigo for very helpful comments. We gratefully acknowledge financial aid from the MEC (SEJ2005-08110) and from the INSIDE program launched by the Institute for Economic Analysis (CSIC). The authors can be reached at libertad.gonzalez@upf.edu and francesc.ortega@upf.edu. 


\section{Introduction}

This paper investigates empirically the channels through which open economies absorb large immigration flows. We exploit the large immigration wave received by Spain in the period 2001-2006 and study its effects on the structure of regional employment at the industry level.

Rising cross-country migration flows over the last decade have revived interest on the economic effects of immigration. ${ }^{1}$ Migration rates are on the rise in poor countries and, at the same time, the recent eastward enlargement of the European Union has sharply increased migration flows across its member states.

It is often the case that the density of immigrants across regions within a country is far from uniform. As a result, it is at the regional level that the social and economic impact of immigration is most visible. Relative to national economies, regional units are tightly interconnected by flows of factors, goods, and ideas. Consequently, absorption of immigration flows in these very open (regional) economies can operate through a variety of channels.

Several decades of research have shown that the effects of immigration flows on wages are surprisingly small. ${ }^{2}$ This has led researchers to explore alternative channels by which economies absorb immigration flows. Building on Hanson and Slaughter (2002), Lewis (2003) provides estimates of the effects of immigration on local labor markets in the US. His analysis confirms that immigration has very small effects on wages, but he finds large effects on the skill composition of employment at the sector level. Taken together, these findings pose a puzzle for standard open economy models. ${ }^{3}$

Our goal is to use data on the recent immigration wave in Spain to investigate the impact of immigration flows on regional economies. In particular, we are interested in comparing the channels of adjustment operating in Spain with those found by Lewis (2003) for the US. We note that immigration flows into Spanish regions in the period 2001-2006 have been massive. We are also interested in investigating whether the large differences in labor market institutions between Spain and the US lead to a differential pattern of absorption of immigration flows.

\footnotetext{
${ }^{1}$ Chiswick and Hatton (2003).

${ }^{2}$ See the surveys in Borjas (1994), Friedberg and Hunt (1995) and Card (2005).

${ }^{3}$ Note that these results are inconsistent with the Rybsczynski theorem, which postulates that changes in the supply of a factor of production in a small open economy affect neither factor prices nor factor intensities at the sector level.
} 
We assemble an annual panel dataset for Spanish provinces covering the period 2001-2006 and use it to estimate the effects of immigration on the structure of regional employment. Specifically, we estimate the role played by changes in sector specialization and in the skill composition of employment at the sector level in absorbing immigration flows. We employ the between-within industry decomposition proposed by Lewis (2003) and formally test the Rybcszynski hypothesis.

In order to provide a causal interpretation of our results we adopt an instrumental variables approach. We build a Card-type instrument for regional immigration flows based on migration networks by country of origin (Card, 2001). Widely used in studies for the US, we are the first to use this instrument in the case of Spain.

Spain's recent immigration experience is spectacular, as illustrated by figure 1. In 1998, the share of the population born abroad was below 3\%. Over the course of three years, it slowly increased to almost 5\%. Between 2001 and 2006 Spain received very large inflows that resulted in a twofold increase in the foreign-born share: from $4.8 \%$ to $10.8 \%$ in just five years. ${ }^{4}$

Like in the US, the density of immigration across Spanish regions varies enormously. Figure 2 reports the foreign-born share in 2006 for the 52 Spanish provinces (age 25-45). ${ }^{5}$ The provinces along the Eastern Mediterranean coast, together with the area around Madrid, display foreignborn shares over $18 \%$. In contrast, in most Western regions less than $6 \%$ of the population is foreign-born.

Our first finding is purely descriptive. Immigration flows have not been skill-neutral. In the typical immigrant-receiving province, immigration has been disproportionately low educated. As a result, immigration regions have experienced a very large relative increase in the supply of low educated workers.

Turning to our estimates, we first show that (unskilled) immigration flows have caused a large increase in (unskilled) employment in the regions of destination. Next, we study the absorption of these labor inflows at the industry level. We find no causal effect of immigration on regional sector specialization, rejecting the Rybcszynski hypothesis. Instead the main channel of absorption has been within-industry changes in the skill composition of sectoral employment. In other words, the typical industry in a high-immigration region has increased the share of loweducated workers in its workforce, relative to the same industry in a low-immigration region.

\footnotetext{
${ }^{4}$ Figures based on registry data for population all ages, as measured on January $1^{\text {st }}$ of each year.

${ }^{5}$ Data from 2006 Spanish Labor Force Survey (EPA).
} 
We also show that the industries that account for most of the absorption have been Manufactures, Agriculture, Hotels \& Restaurants, and Construction. Using wage data for the Construction sector, we show that Lewis' puzzle seems to be present also in the case of Spain. We show that immigration has led to a large relative increase in the use of low-educated workers in the sector, while nominal wages have increased essentially at the same rate as in low-immigration regions. ${ }^{6}$

Our work contributes to the empirical literature analyzing the effects of immigration on open economies. The earlier studies conducted accounting decompositions, as in Hanson and Slaughter (2002), and Gandal, Hanson and Slaughter (2005). We follow the more recent studies that provide estimates of causal effects, as Lewis (2003) and Dustmann and Glitz (2007). ${ }^{7}$

Of course our work is also related to the large body of literature on the labor market effects of immigration, mostly focused on the US case. ${ }^{8}$ In particular, our paper adopts the spatial correlations approach pioneered by Altonji and Card (1991), and widely used since then. For an influential, recent application of this method see Ottaviano and Peri (2006). Our paper is also closely related to the immigration literature studying the case of Spain. The earliest paper we are aware of is Dolado, Jimeno, and Duce (1998). A few of the recent contributions are Carrasco, Jimeno, Ortega (2007), and Amuedo-Dorantes and De la Rica (2005). In comparison to these studies, our paper has several novel features. Our data covers the period with the largest inflows, 2001-2006 and we work with a more disaggregated classification of regions (52 provinces). More importantly, we adopt a multi-sector framework that highlights the open-economy nature of regional economies. Finally, we are the first to build an instrument for immigration flows based on migration networks (à la Card) for the case of Spain. Our work is also related to the recent descriptive analysis of the demographic impact of immigration in Spain (Recaño, 2004 and Domingo and Martínez, 2006).

Finally, this paper is also related to the recent economic growth literature studying the role of human capital in fostering technology adoption. Using cross-country panel data, Ciccone and Papaioannou (2007) find evidence in support of the Rybcszynski theorem. Their results suggest that countries that have experienced larger increases in human capital in recent decades have

\footnotetext{
${ }^{6}$ Specifically, we find that the share of high-school dropouts in Construction has fallen in all provinces. However, it has dropped much less in high-immigration regions.

${ }^{7}$ Mayda and Rodrik (2005) analyze the impact of individual exposure to international trade on attitudes toward immigration. Mayda (2006) and Facchini and Mayda (2007) also analyze the determinants of individual attitudes toward immigrants.

${ }^{8}$ We note the early contributions of Card (1990) and Borjas, Freeman and Katz (1996).
} 
also displayed faster growth in skill-intensive industries. Their interpretation is that human capital helps adopt new (skill-biased) technologies.

The structure of our paper is as follows. Section 2 describes our main data sources. Section 3 presents a descriptive analysis of the size and skill composition of immigration flows. Section 4 presents the empirical model and discusses some econometric issues. Section 5 contains the main results. Section 6 focuses on the Construction industry. Section 7 concludes. The appendices contain the figures and tables.

\section{Data sources}

Our main sources are the 2001 and 2006 Spanish Labor Force Survey (EPA) and the decennial Census for 1991. The EPA contains detailed individual-level information on province of residence, years of education, age, country of birth, and employment by industry. We take the 52 Spanish provinces as our unit of analysis, and will refer to them as regions. We define immigrants as foreign-born workers, and make use of information in the EPA regarding the number of years of residence in Spain. Throughout the analysis we consider three education levels: individuals without a high school degree, individuals with a high school degree (but no college degree), and individuals with completed university studies. The industry classification is CNAE 1993, and we use a 2-digit and a 3-digit classification, with 16 and 30 industries, respectively.

We restrict the analysis to population in the age group 25-45. We discard very young individuals to obtain reasonable estimates of the fraction of the population with university education, and we discard individuals approaching retirement to reduce the number of interregional migrants driven by retirement motives. In addition, the density of foreign-born individuals is higher in this age group (see figure 1), which reduces measurement error in province-education cells.

We denote by $\mathrm{L}_{\mathrm{e}, \mathrm{r}}$ the total population (natives and immigrants) in province " $\mathrm{r}$ " with education level "e", and by $\mathrm{M}_{\mathrm{e}, \mathrm{r}}$ the foreign-born individuals that entered Spain between 2001 and 2006 (the "migration inflow"). Aggregating over education groups, we define $L_{r}$ and $M_{r}$. Let us also define $\mathrm{N}_{\mathrm{e}, \mathrm{r}}$ as the total employment (including both natives and immigrants) for a given province and skill group.

Table 1 summarizes our data (for population ages 25-45). The average percentage increase in the population of Spanish regions over the period was $10.15 \%$. By education levels, we note the 
$29 \%$ reduction in the size of the high-school dropout group in the average province, and the increases of $24 \%$ and $22 \%$ for the high-school graduate, and college graduate groups, respectively. Note also the large cross-sectional variation in all education groups.

The last section of the paper uses regional data on wages for the Construction sector. Those data are based on collective bargaining agreements negotiated at the province level. We shall provide further details on those data later on. ${ }^{9}$

\section{The impact of immigration on regional skills}

Since 2001 immigration flows into Spain have increased dramatically (see figure 1). The impact of these inflows on the size and skill composition of the Spanish labor force has been very large. As can be seen in table 1, over the period 2001-2006 the inflows of foreign-born population have led to an $8.97 \%$ population growth in the average province, accounting for $90 \%$ of the population growth in the period.

These immigration flows have not been skill-neutral. The foreign-born workers arriving in Spain in the last five years have fuelled an increase of $14.33 \%, 8.98 \%$, and $7.35 \%$, respectively, in the size of the low, medium, and high education population (ages 25-45), as shown in table 1. Immigration has thus led to an increase in the relative supply of low educated labor in the average province.

Another salient feature of the recent Spanish immigration experience is its highly unequal regional impact. Figure 2 reports the foreign-born share for Spanish provinces in 2006 (ages 2545). In the provinces lying on the Mediterranean and around Madrid, over 20\% of the population was foreign-born. In contrast, in most of the South and West of the country the foreign-born share was below $5 \%$.

The impact of immigration on skill composition systematically differed between regions of high and low immigration. Let us classify provinces by the size of the total inflows relative to the initial population, that is, $\mathrm{M}_{\mathrm{r}} / \mathrm{L}_{\mathrm{r}}(2001)$. As shown in table 2a, Almeria, Tarragona and Alicante (all on the Mediterranean coast) immigration flows led to population growth ranging between 19 and 38\%, compared to $7 \%$ in the median province. We also note that Barcelona and Madrid received inflows above the median. Next, we define as high-immigration regions those with

\footnotetext{
${ }^{9}$ More standard wage data can be found in the "Wage Structure Survey", carried out every four years. As of now, the last available data wave is for 2002. In addition, the highest available regional disaggregation is at the autonomous community level. There are 17 such regions, typically, including several (of the 52) provinces.
} 
total relative inflows above the median. The remaining regions are considered low immigration regions.

Table $2 \mathrm{~b}$ reports mean values for each set of regions. First, note that immigration flows led to a $14.26 \%$ increase in the population of high immigration regions, compared to only $3.67 \%$ in lowimmigration regions. In the latter, immigration flows were not only small but also roughly skillneutral. In low-immigration regions, immigration led to a $4.97 \%$ increase in high-school dropouts (HSD) and a 3.84\% increase in college graduates (COG). In sharp contrast, immigration was disproportionately low educated in high immigration regions, with a $23.68 \%$ increase in HSD but only a $10.87 \%$ expansion in COG.

The figures in the table also suggest that in the absence of immigration, the changes in the skill distributions of the two sets of provinces would have been roughly similar. Namely, the average low immigration region would have experienced a $45 \%$ reduction in the HSD population and a $13 \%$ increase in COG. In comparison, the typical high-immigration region would have featured a $32 \%$ drop in HSD and a $16 \%$ increase in COG. Hence, it appears that immigration has been responsible for the large gap in skill upgrading between high and low immigration regions. While the HSD group has shrunk by more than 50\% in the latter regions, it has dropped by less than $8 \%$ in high-immigration regions.

Summing up, the main effect of immigration flows in the period 2001-2006 on the skill distribution of Spanish regions has been to substantially increase the relative supply of loweducated workers. We next describe the framework to analyze the effects of this change in relative skills on the structure of production of Spanish regions.

\section{Framework}

\subsection{A multi-sector setup}

We view each province as a small open economy. There are $\mathbf{J}$ final goods (sectors), produced using three types of labor, differentiated by skill (education) levels. Within education groups natives and immigrants are considered perfect substitutes. ${ }^{10}$ Labor markets are assumed to be local, whereas final goods markets are global.

\footnotetext{
${ }^{10}$ For a recent line of work departing from this assumption see Ottaviano and Peri (2006) and Peri and Sparber (2007).
} 
Let $\left(\mathrm{L}_{1}, \mathrm{~L}_{2}, \mathrm{~L}_{3}\right)$ denote the economy's endowment of workers by skill type, and let $N_{e}^{j}$ be the number of workers with skill level $e=1,2,3$, employed in the production of final good $\mathrm{j}$. We assume that all sectors have constant returns to scale in the three labor inputs: ${ }^{11}$

$$
y^{j}=f^{j}\left(N_{1}^{j}, N_{2}^{j}, N_{3}^{j}\right)=N^{j} f^{j}\left(\lambda_{1}^{j}, \lambda_{2}^{j}, \lambda_{3}^{j}\right)
$$

where $N^{j}$ denotes total employment in sector $\mathrm{j}$, and $\lambda_{e}^{j}$ is the fraction of e-type employment in that sector $\left(\mathrm{N}_{\mathrm{e}, \mathrm{j}} / \mathrm{N}_{\mathrm{j}}\right)$. We also assume that some workers are unproductive and are not employable by any sector. ${ }^{12}$ As a result, the total population with a given education level can be written as the sum of the unemployed (unproductive workers) plus employment in all sectors. That is, for each skill $\mathrm{e}=1,2,3$, we have

$$
L_{e}=U_{e}+N_{e}=U_{e}+\sum_{j=1}^{J} \lambda_{e}^{j} N^{j}
$$

\subsection{A useful accounting identity}

Our empirical application aims at estimating the effects of shocks to a region's labor endowments on the industry structure of employment.

Prior to disaggregating by sector, let us consider the following decomposition. After a bit of algebra, ${ }^{13}$ one can easily show that

$$
\frac{\Delta L_{e}}{L_{e, 0}}=\frac{N_{e, 0}}{L_{e, 0}}\left[\% \Delta N_{e}\right]+\frac{U_{e, 0}}{L_{e, 0}}\left[\% \Delta U_{e}\right] .
$$

where period 0 is the initial period. In words, a $1 \%$ increase in the size of a skill group is the appropriately weighted sum of the percentage increases in employment and "unemployment" (including both employment and net exits from the labor force).

Let us now disaggregate employment by sector. To fix ideas, let us begin by considering an inflow of unskilled workers into a region, with no changes in the size of the other skill groups. Some of the new workers may be unproductive and will become unemployed. The rest will be

\footnotetext{
${ }^{11}$ Alternatively, we can interpret that goods are produced using the three types of labor plus physical capital, and each region faces a perfectly elastic supply of capital. Production displays decreasing returns to scale in the labor inputs, but constant returns to scale in all four inputs. Our technology with constant returns to scale in the labor inputs can be seen as a reduced form for this environment. Our empirical model will also impose constant elasticity of substitution across all education groups.

${ }^{12}$ This is just a shortcut to introduce unemployment in the model.

${ }^{13}$ See Lewis (2003) for details.
} 
absorbed through increases in the employment of unskilled workers in one or more industries. This expansion in unskilled employment at the industry level can reflect a) an increase in the scale of those industries, at constant relative factor intensities, b) an increase in the intensity of use of unskilled labor, for a constant scale of production in those industries, and c) an increase in unskilled labor demand arising from simultaneous changes in both the scale and the factor intensities in those industries. As we shall discuss below, Hecksher-Ohlin theory has precise implications as to which of these channels should drive the absorption process.

More generally, consider a change in a region's skill endowments between periods 0 and 1 :

$$
\left(\% \Delta L_{1}, \% \Delta L_{2}, \% \Delta L_{3}\right) \quad \text { where } \% \Delta L_{e}=\frac{L_{e, 1}-L_{e, 0}}{L_{e, 0}} .
$$

A bit of algebra delivers the following accounting identity. For each education group e=1,2,3, the absorption of a change in the size of the group can be decomposed into an increase in unemployment (UE), a purely between-industry adjustment (B), a purely within-industry adjustment (W), and an interaction term (I). That is,

$$
\begin{aligned}
\% \Delta \mathrm{L}_{\mathrm{e}} & =\mathrm{UE}_{\mathrm{e}}+\left[\mathrm{B}_{\mathrm{e}}+\mathrm{W}_{\mathrm{e}}+\mathrm{I}_{\mathrm{e}}\right] \\
& =\left(1-\sigma_{\mathrm{e}, 0}\right)\left[\% \Delta \mathrm{U}_{\mathrm{e}}\right]+\sum_{\mathrm{j}}{\sigma_{\mathrm{e}, 0}^{j}}^{j}\left[\mathrm{H}^{\mathrm{j}}\right]+\sum_{\mathrm{j}} \sigma_{\mathrm{e}, 0}^{j}\left[\% \Delta \lambda_{\mathrm{e}}^{j}\right]+\sum_{\mathrm{j}} \sigma_{\mathrm{e}, 0}^{j}\left[\% \Delta N^{j}\right]\left[\% \Delta \lambda_{\mathrm{e}}^{j}\right]
\end{aligned}
$$

where $\sigma_{e, 0}^{j}$ is the initial share of sector j's employment in the total population with education level e $\left(\mathrm{N}_{\mathrm{e}, \mathrm{j}} / \mathrm{L}_{\mathrm{e}}\right)$, and $\sigma_{e, 0}$ is the initial employment-population ratio for education level e $\left(\mathrm{N}_{\mathrm{e}} /\right.$ $\mathrm{L}_{\mathrm{e}}$ ). In other words,

$$
\sigma_{e, 0}^{j}=\frac{N_{e, 0}^{j}}{L_{e, 0}}, \quad \lambda^{j}{ }_{e}=\frac{N_{e}^{j}}{N^{j}}, \quad \sigma_{e, 0}=\sum_{j} \sigma_{e, 0}^{j} .
$$

We can now derive a test for Rybcszynski effects using this decomposition. ${ }^{14}$ According to the Rybcszynski theorem, under certain conditions, an exogenous increase in the size of a skill group in the economy will be absorbed by a change in the sectoral distribution of output (and employment) in the economy, with no changes in relative factor intensities in any sector or in equilibrium wages. Intuitively, what would happen under Rybcszynski is that the average HSDintensive sector expands its production (and total employment), raising the content of HSD labor in the exports to other regions. In terms of our previous decomposition, the Rybcszynski theorem implies

$$
\% \Delta L_{e}=U E_{e}+B_{e}
$$

\footnotetext{
${ }^{14}$ For an excellent account of the Rybczynski theorem and its empirical implications, see Leamer (1995).
} 
since relative factor intensities remain constant in all industries. ${ }^{15}$

\subsection{Empirical model}

The core of our analysis is the estimation a series of regression models that share the same righthand side variables but differ in their dependent variable. Equipped with these models we attempt to explain what fraction of the changes in skill groups in the data have been absorbed by a) changes in unemployment, b) between-industry changes in employment, c) within-industry changes in employment, and d) an interaction of the latter two channels. More specifically, we postulate that

$$
\begin{aligned}
& U E_{e, r}=\alpha_{r}+\alpha_{e}+\beta_{U E}\left[\% \Delta L_{e, r}\right]+\varepsilon_{e, r} \\
& B_{e, r}=\alpha_{r}+\alpha_{e}+\beta_{B}\left[\% \Delta L_{e, r}\right]+\varepsilon_{e, r} \\
& W_{e, r}=\alpha_{r}+\alpha_{e}+\beta_{W}\left[\% \Delta L_{e, r}\right]+\varepsilon_{e, r} \\
& I_{e, r}=\alpha_{r}+\alpha_{e}+\beta_{I}\left[\% \Delta L_{e, r}\right]+\varepsilon_{e, r},
\end{aligned}
$$

where $\alpha_{\mathrm{r}}$ and $\alpha_{\mathrm{e}}$ are region and education fixed effects, respectively. We allow the slope coefficient $\beta$ to vary across models, however we impose symmetric values across education levels. ${ }^{16}$

The region fixed effects capture any regional differences in labor demand that are common to all education groups. For example, we are allowing for differences in regional growth rates for total factor productivity. The education fixed effects control for global changes in the relative demand for each type of labor, for instance due to skill-biased technical change.

\subsection{Endogenous location choices}

A proper test of the Rybcszynski theorem requires identifying an exogenous shock to the skill composition of the labor force. In the absence of natural experiments, this is not straightforward. In particular, our analysis may be corrupted by spurious correlations arising from the endogeneity of immigrants' location choices. More specifically, it may be the case that immigrants with a particular skill choose to locate in regions that display high growth in the demand for that skill (unobserved by the econometrician).

\footnotetext{
${ }^{15}$ In the standard rendition of the theorem all workers are productive and hence the unemployment term is zero. In any case, all of the increase in employment is due to the between-industry component.

${ }^{16}$ This is the case when sector-specific production functions are CES.
} 
We follow Lewis (2003) and adopt an instrumental variables approach inspired in Card (2001). Our aim is to build a variable that is correlated with changes in a region's skill group over the period 2001-2006, but is uncorrelated with current shocks to the region's demand for that type of labor. We base our instrument in a robust feature of immigration flows: the existence of migration networks. Immigrants tend to locate in regions (or even neighborhoods) with existing clusters of immigrants from their same country of origin. ${ }^{17}$ While this instrument has been widely used to study the effects of immigration in the US, we are the first to apply it to the case of Spain.

More specifically, let $M_{e, c}^{S p, 2001-2006}$ denote the Spain-wide immigration flows during the period 2001-2006 from country of origin "c" and with education level "e". Our instrument "allocates" these individuals to Spanish provinces using the cross-sectional distribution of immigrants in 1991 for each country of origin. These distributions are the result of immigration waves that occurred during the 1980s, and are likely to reflect differences in regional economic conditions at the time. Let $\pi_{r, c}(1991)$ denote the share of all immigrants born in country c living in Spain in 1991 that were located in province r. We build the imputed 2001-2006 inflow from country c with education e into province $r$ by assigning actual Spain-wide inflows using 1991 weights, and denote it by $Z_{e, r, c}$. Finally, we sum over all countries of origin, so that our instrument, $Z_{e, r}$, is defined by:

$$
Z_{e, r}=\sum_{c=1}^{C} Z_{e, r, c}=\sum_{c=1}^{C} \pi_{r, c}^{1991} M_{e, c}^{S p, 2001-2006}
$$

\section{Results}

\subsection{First-stage regressions}

Having constructed our instrument for immigration flows at the education-region level, we next examine its predictive power, first, in predicting actual flows and then regarding total population changes in education-region cells. This instrument based on immigration networks has been shown to be valid for the US, a country with a long history of immigration. Beforehand it is unclear whether the instrument will have predictive power in the case of Spain, where immigration only started timidly during the second half of the 1980s and has accelerated over the course of the 1990s.

\footnotetext{
${ }^{17}$ For a theoretical analysis of migration networks see Carrington et al (1996).
} 
Let us first consider the ability of our instrument to predict actual flows. We do so by estimating

$$
M_{e, r}=\delta Z_{e, r}+\alpha_{e}+\mu_{r}+\varepsilon_{e, r},
$$

where we include region and education fixed effects. As reported in table 3, imputed inflows are a strong predictor of actual inflows, with a coefficient of 0.78 in the levels specification and 1.39 when using ratios over the initial size of each skill group. Furthermore, we examine the relationship country by country. As the lower panel shows, imputed inflows predict well actual flows for the main source countries (Morocco, Argentina, Other South American countries).

Let us now turn to predicting total changes in skill groups. This relationship is important because it corresponds to the first-stage regressions in the subsequent analysis. In our main regressions, the key explanatory variable will be $\% \Delta \mathrm{L}_{\mathrm{e}, \mathrm{r}}$, the change in the size of a region's skill group. To explore the predictive power of our instrument we thus estimate

$$
\frac{\Delta L_{e, r}}{L_{e, r}^{2001}}=\delta \frac{Z_{e, r}}{L_{e, r}^{2001}}+\alpha_{e}+\mu_{r}+\varepsilon_{e, r} .
$$

Clearly, changes in the total size of a skill group are the sum of changes in the Spain-born population and changes in the foreign-born population living in that region. The regression above showed that our instrument is able to predict inflows of immigrants by education into a region. Conceivably, (foreign) immigration into a region could trigger off-setting inter-regional flows of Spain-born workers that could leave the total size of the region's skill group unaffected. ${ }^{18}$

However, this is not the case here, as shown in table 4. In all specifications imputed educationregion inflows significantly predict total changes in region-skill groups. In our baseline specification the coefficient is 1.18 , with a t-statistic of 4.43 . Our preferred specification (column 5) excludes outliers and reports robust standard errors. Here the coefficient is 4.63 and the t-statistics is $7.35 .^{19}$

\subsection{Aggregate employment}

Let us now consider an inflow of workers of a particular skill level into a region. The goal of this section is to estimate what fraction of the inflow becomes employed, as opposed to increases in unemployment (or in the population out of the labor force). We shall use our instrument to deal with the endogeneity of migrants' location choices.

\footnotetext{
${ }^{18}$ The issue of natives' displacement has been studied by Borjas, Freeman and Katz (1996), and Card and DiNardo (2000), with US data.

${ }^{19}$ We prefer a specification that does not weight observations because it is theoretically unclear what the appropriate weights should be.
} 
The regression we estimate is

$$
\frac{N_{e, r}^{2001}}{L_{e, r}^{2001}}\left[\% \Delta N_{e, r}\right]=\beta \frac{\Delta L_{e, r}}{L_{e, r}^{2001}}+\alpha_{e}+\mu_{r}+\varepsilon_{e, r}
$$

and coefficient $\beta$ is interpreted as the fraction of the skill inflow that is absorbed through an expansion in the employment of that skill group in the region. Note that (1- $\beta$ ) is the fraction of the inflow that is absorbed through an expansion in non-employment.

Table 5 presents the estimates. Both the OLS and IV estimates are around 0.7 and highly significant. Our preferred estimates are in column 5. This specification features region and education fixed effects, robust standard errors, and is estimated in a sample without outliers. According to our IV estimates, $72.8 \%$ of an inflow of a particular skill type is absorbed through an increase in employment. Put differently, $27.2 \%$ of the inflow ends up unemployed (or does not enter the labor force). These figures are consistent with immigration having no effect on the overall employment-population ratio.

We also note that the endogeneity problem seems to be greatly mitigated with the inclusion of province fixed effects. Consider the first column in table 5, where we do not include region fixed effects. Here the instrumental variables estimate is substantially lower than the corresponding OLS coefficient.

\subsection{Between-industry adjustment}

As we saw earlier, the increase in region-education employment can be decomposed in a between-industry adjustment, a within-industry adjustment, and an interaction term.

We now estimate the size of the between-industry adjustment. This will provide a test of the Rybcszynski effect, which predicts that an exogenous inflow of workers with a particular skill type into a region will be absorbed by changes in the sectoral composition of output and employment, leaving the skill composition of sectoral employment and relative wages unchanged. Specifically, the Rybcszynski hypothesis is $\beta_{\mathrm{B}}=1$ in the following regression model (that is, if we assume that no absorption takes place through increases in unemployment):

$$
B_{e, r}=\beta_{B} \frac{\Delta L_{e, r}}{L_{e, r}^{2001}}+\alpha_{e}+\mu_{r}+\varepsilon_{e, r} .
$$

Recall that the dependent variable can be interpreted as the increase in regional employment for skill group e arising from an increase in the scale of the typical sector employing that type of labor, keeping constant the relative factor intensities of all sectors at 2001 values. 
Table 6a presents the results. The OLS estimate is positive and significantly different from zero but the magnitude is quite small (and significantly below 1). The point estimate implies that only about $5 \%$ of the inflow is absorbed through the between-industry channel. As a share of the increase in employment, the OLS coefficient implies that only $11 \%$ of the increase in employment can be accounted for in this manner. The IV estimate is 0.034 , not significantly different from zero and far from the value of 1 predicted by the Rybcszynski hypothesis. The last two panels in the table show that restricting to traded sectors (as required by the theorem) the estimated coefficient becomes even smaller. ${ }^{20}$

\subsection{Within-industry adjustment}

Let us now turn to estimating what fraction of the inflow can be explained by a purely withinindustry adjustment. We note that this would be an important channel of adjustment in a multisector, closed-economy model (together with the interaction term). But note that in such a model changes in the skill composition of employment at the sector level must be associated to changes in relative wages.

We now estimate

$$
W_{e, r}=\beta_{W} \frac{\Delta L_{e, r}}{L_{e, r}^{2001}}+\alpha_{e}+\mu_{r}+\varepsilon_{e, r},
$$

where the dependent variable can be interpreted as the increase in the employment of skill group "e" arising from a more intensive use of that type of labor in the employment of the typical sector, while keeping constant the relative scale of all sectors at 2001 values. Note also that this specification provides a second test of the Rybcszynski theorem: $\beta_{\mathrm{W}}=0$.

Table 7a displays the results. In our preferred specification the IV point estimate is $0.59(0.57 \mathrm{in}$ OLS), highly significant. This estimate implies that $59 \%$ of an inflow of a skill type ( $81 \%$ of the increase in employment) is absorbed through increases in employment that are consistent with a pure substitution of other types of labor for the now more abundant type. The bottom panel shows the results when only using traded sectors. The IV coefficient drops to 0.31 , since we are now only capturing the absorption by a subset of industries.

\footnotetext{
${ }^{20}$ Here we use the classification for traded sectors used in Lewis (2003), following Hanson and Slaughter (2002). In any case, later in the paper we estimate separate regressions for each industry. For a theoretical analysis with nontraded goods, see Ethier (1972).
} 


\subsection{Overview}

Recall from equation (4) that there is one more channel of absorption, consisting of an interaction between changes in sector factor intensities and sector sizes. By construction, this term can readily be calculated from the above estimates as the difference between the absorption through aggregate employment (one minus the increase in non-employment) and the between and within industry adjustment coefficients:

$$
\beta_{I}=1-\beta_{U E}-\beta_{B}-\beta_{W}=\beta_{E}-\beta_{B}-\beta_{W} .
$$

The top panel in table 8 presents a summary of the contribution of each channel to the absorption of an inflow of a skill group into a region. As already discussed, $27 \%$ of the inflow is absorbed through increases in non-employment, 3.4\% through between-industry increases in employment, $59 \%$ through within-industry increases, and $11 \%$ due to the interaction term. Overall, these results imply rejecting the hypotheses of Rybcszynski effects (both through the between and within industry tests).

Perhaps surprisingly, given the large institutional differences between the labor markets of Spain and the US, the pattern of adjustment that we find is very similar to the one found by Lewis (2003) for US metropolitan areas.

One caveat to keep in mind in testing for Rybcszynski effects is that the results may be sensitive to the degree of disaggregation in the industry classification. The coarser the partition is, the higher the fraction of between-industry changes that will be misclassified as being intraindustry. To address this issue we repeat the analysis at the greatest level of industry disaggregation that is feasible with our data (30 industries, compared to 16 in our baseline estimation).

The bottom panel in table 8 reports our results (with more details in tables $6 \mathrm{~b}$ and $7 \mathrm{~b}$ ). We note that the between-industry adjustment remains practically unchanged (IV estimate goes from 0.034 to 0.037 ). This result suggests that further disaggregation is not likely to overturn the rejection of the Rybcszynski hypothesis based on the between-industry estimate. The withinindustry coefficient falls from 0.59 to 0.41 while, at the same time, the interaction coefficient increases from 0.11 to 0.28 .

\subsection{Industry results}

We next turn to analyze the contribution of each industry in the adjustment process. This will provide insights that may be helpful in uncovering the mechanisms behind the adjustment in the case of Spain. 
Let us start first with the between-industry adjustment. Recall that the between-industry adjustment corresponds to a weighted average of growth rates for all sectors, measured by increases in total employment:

$$
\mathrm{B}_{\mathrm{e}}=\sum_{\mathrm{j}} B_{e}^{j}=\sum_{\mathrm{j}} \sigma_{\mathrm{e}, 0}^{j}\left[\% \Delta \mathrm{N}^{\mathrm{j}}\right] .
$$

We are now interested in the fraction of the change in the supply of a given skill group absorbed by each industry $\mathrm{j}$. More specifically, we regress the between-industry term for each industry, $B_{e}^{j}$, on changes in the supply for that skill group. Table 9 reports the results. We note that the construction industry alone accounts for most of the between-industry adjustment: the increase in the scale of this industry accounts for $2.9 \%$ of the absorption of the inflow (compared to a $3.4 \%$ when all industries are considered). Our instrumental variables approach allows for a causal interpretation of these results: immigration has triggered an expansion of the construction sector in Spain. ${ }^{21}$

Let us now turn to the role played by each industry in the within-industry adjustment. The dependent variable in our regressions is now the industry-weighted percentage change in the fraction of employment of a given skill type over total industry employment:

$$
\mathrm{W}_{\mathrm{e}}=\sum_{\mathrm{j}} \mathrm{W}_{\mathrm{e}}^{\mathrm{j}}=\sum_{\mathrm{j}} \sigma_{e, 0}^{j}\left[\% \Delta \lambda_{e}^{j}\right]
$$

The right-hand side panel in table 9 reports the results of regressing $W_{e}^{j}$ on $\% \Delta \mathrm{L}_{\mathrm{e}, \mathrm{r}}$, including education and region fixed effects. As we saw earlier, the within-industry adjustment accounts for $58.6 \%$ of a given inflow. By individual industries, we obtain positive and significant (IV) effects for seven industries, with the lion's share of the adjustment being carried out by Manufactures (17.3\%), Agriculture (10.2\%), Hotels and Restaurants (9.5\%), Construction (9.3\%), Retail (6\%), and Domestic Services (2.6\%). We note that the magnitude of the role played by each industry reflects both the technological possibilities for substitution across education types in the sector, and its relative size in the region's aggregate employment.

\section{The Construction industry}

The results in the previous section suggest that Spanish regions have absorbed immigration flows in the period 2001-2006 much in the same manner as metropolitan areas in the US did during the 1980s (Lewis, 2003). Absorption of immigration flows in the affected regions has

\footnotetext{
${ }^{21}$ Of course, immigration has also increased the total demand for many other goods, which may also have contributed to output growth.
} 
mainly taken place through an increase in the relative intensity of the skills that have become more abundant in most industries.

Lewis (2003) finds a very small impact of immigration flows on the wage structure of US metropolitan areas. Taken together with the large changes in relative factor intensities at the industry level, this finding presents a puzzle for traditional open-economy theories. Recent work is attempting to reconcile these findings using theories where firms choose their production function in response to shocks to the skill distribution in their local labor markets.

The results in Dustmann and Glitz (2007) also suggest the existence of a similar puzzle for the German economy. Is this also the case for Spain? Addressing this question requires wage data at the province-education level, which is unavailable for the case of Spain. While these wage data are not available for all industries, they do exist for the construction sector for our period of interest.

The goal of this section is thus to estimate the effects of immigration on the structure of regional wages and relative factor intensities using data for the construction sector. Studying the impact of immigration on the structure of production of the construction sector is interesting by itself, given the key role this industry has played in generating employment for the recent wave of immigrants.

The data on construction wages has been assembled by UGT, one of the two main labor unions in Spain, on the basis of province-level collective bargaining for the construction sector. The data are annual, span the period 2002-2006, and report wages for several professional categories. We note that these bargained wages are minimum wages. However, since they are decided at the province (and sector level) they reflect relative supply and demand conditions. ${ }^{22}$ The lowest paid category requires no formal training and workers are often high-school dropouts ("peon ordinario"). The intermediate category in terms of wages includes more experienced workers ("oficial administrativo de primera"). The top category ("titulado superior") refers to workers with university degrees. On this basis, we label each of these groups as low, medium, and high skilled, and equate them to the education groups used throughout the paper: high-school dropouts, high-school graduates, and college graduates. ${ }^{23}$

\footnotetext{
${ }^{22}$ See also the discussion on the availability of wage data for Spain in footnote 8 .

${ }^{23}$ Other studies with this type of wage data are Bentolila and Jimeno (2002), Dolado, Felgueroso, and Jimeno (1997), and Simón-Pérez (2001).
} 
The top panel in table 10 summarizes the cross-sectional data for year 2006. Average wages across all provinces were $14,219 €, 16,796 €$, and 22,627€, for low, medium, and high skilled construction workers. Note also the large cross-sectional dispersion in the table within each category. Roughly speaking, the province with the highest wages pays about twice what is paid in the lowest-pay province for a worker with the same skill level.

The bottom panel shows that there is also a great deal of dispersion in wage growth over the period 2002-2006. ${ }^{24}$ The average increase ranges between $23 \%$ and $25 \%$ across all professional categories. Again, there is a lot of regional variation. For instance, for the lowest skill group the 5 -year growth rate ranged between $8 \%$ and $35 \%$. Variation was even higher for the other two professional categories.

We now turn to estimating the effect of changes in the supply of each skill group on the construction sector. We start by estimating the effect on relative factor intensities. Since we are interested in measuring the impact on the skill composition of employment in the sector, as opposed to the share of the total absorption carried out by this particular industry, we do not weigh the dependent variable. Specifically, our regression is

$$
\Delta \lambda_{e, r}^{\text {cons }}=\beta \frac{\Delta L_{e, r}}{L_{e, r}^{2001}}+\alpha_{e}+\mu_{r}+\varepsilon_{e, r} .
$$

In this case, $\beta$ measures the impact of a $1 \%$ change in the size of a skill group on the fraction of construction workers with that skill level. The first panel in table 11 reports the OLS and IV results. As expected, the effect is positive and significant. For each $10 \%$ increase in the size of a skill group, its share of total employment in Construction increases by 1.7 percentage points.

Let us now turn to estimating the effects on the wage structure. We estimate the following model:

$$
\% \Delta w_{e, r}^{c o n s}=\beta \frac{\Delta L_{e, r}}{L_{e, r}^{2001}}+\alpha_{e}+\mu_{r}+\varepsilon_{e, r},
$$

where the dependent variable is the percentage increase in the wage of construction workers with skill level "e" in province " $\mathrm{r}$ ". The second panel in table 11 reports our estimates. We find a negative point estimate, both for OLS and IV, but not significantly different from zero. Taking the IV point estimate at face value, a $10 \%$ inflow of high-school dropouts into a region would reduce the wages for this type of workers (in Construction) by $0.1 \%$.

\footnotetext{
${ }^{24}$ Our data cover 2002-2006, but the figures reported are re-scaled to a 5-year period. That is, we annualized the growth rate and multiplied by 5 .
} 
Let us now use the estimated model to provide a quantitative assessment of the impact of immigration on the Construction sector, taking into account the actual changes in the size and skill composition of regional labor forces. In particular, we compare the predicted values for the average high and low immigration regions, as defined in table 2.

As shown in table 12, demographic changes in low-immigration regions over the period 20012006 entailed a reduction of $51 \%$ in the population with less than a high-school degree, together with increases of $19 \%$ and $17 \%$ in the populations with a high-school degree and with a college degree, respectively. According to our estimates, the construction sector in these regions should have experienced, as a result, a reduction of 12 percentage points in the share of construction workers with less than a high-school education, together with increases in the fractions of workers with higher education levels. At the same time, (nominal) wages would have increased by $23 \%$ for high-school dropout workers in construction in these regions.

As argued earlier, the large immigration flows in many Spanish provinces led to a very different evolution in the size and skill composition of the regional labor force. In these regions the population with less than a high-school degree fell only by $8 \%$, while the groups with a highschool and college degree increased by $28 \%$ and $27 \%$. According to our estimated model, this would have led to a much smaller reduction in the share of high-school dropouts in the construction sector in these regions. It would only fall by 5 percentage points, compared to 12 points in the low-immigration regions. The increases in the shares of the other skill groups were only slightly larger than in low-immigration regions. However, the wages of high-school dropouts in high-immigration regions increased at roughly the same rate as in low-immigration regions. $^{25}$

\footnotetext{
${ }^{25}$ Taking out point estimates at face value, we predict that immigration led to an increase in high-school dropout wages in construction that was $0.4 \%$ lower than in low-immigration regions. We remind the reader that the estimated coefficient for the effect on wages was not significant. In our data, total employment in Construction grew by $60 \%$ in high immigration regions, as compared to only $15 \%$ in low immigration regions.
} 


\section{Conclusions}

This paper has documented the characteristics of the large immigration wave received by Spain in the period 2001-2006. We have shown that the impact of immigration on the skill composition of regional labor forces can be described as a large increase in the relative supply of low-educated labor. At the same time, over the period considered the Spanish workforce was undergoing strong cohort skill upgrading. As a result, while low immigration regions experienced a $50 \%$ reduction in the population with less than a high school degree, the size of this skill group fell by less than $8 \%$ in high immigration regions.

According to our estimates, the main channel of absorption of these changes in regional labor supplies has been a within-industry substitution from more to less educated workers. As illustrated by the changes in the Construction industry, in low immigration regions the fraction of Construction employment with less than a high school degree fell by 12 percentage points over the period 2001-2006. In contrast, the fraction of high-school dropout employment in highimmigration regions only fell by 5 percentage points. However, the wages for workers with equal education levels grew at the same rate in both groups of regions. Qualitatively, this is the same pattern of adjustment to local immigration shocks found for the US in previous studies.

As we discussed, these findings seem inconsistent with standard Heckscher-Ohlin models. Currently, immigration economists are busy searching for explanations to this apparent puzzle. A promising venue builds on the idea that production technology is chosen to complement the skill composition of the local workforce. ${ }^{26}$ While showing promise, there is still a lot of work to be done in demonstrating that this mechanism can account for the empirical patterns documented for the US, Germany, and Spain. Additionally, a satisfactory explanation should be consistent with the recent findings of imperfect substitution between natives and immigrants with similar education levels (Peri and Sparber, 2007).

\footnotetext{
${ }^{26}$ See Lewis (2005) for some supportive evidence for the case of the US. The cross-country findings in Ciccone and Papaioannou (2007) also suggest a link between skills and technology adoption. However, they also find evidence of changes in the sector composition of output.
} 


\section{References}

Altonji, J., and Card, D. (1991). "The effects of immigration on the labor market outcomes of less skilled natives", in John M. Abowd and Richard B. Freeman (eds.), Immigration, Trade, and the Labor Market, pp. 201-31, Chicago: The University of Chicago Press.

Amuedo-Dorantes, C., De la Rica, S. (2005). "Immigrants' Responsiveness to Labor Market Conditions and Its Implications on Regional Disparities: Evidence from Spain," IZA Discussion Paper No. 1557, April 2005.

Bentolila, S., Jimeno, J.F. (2002). "The reform of collective bargaining in Spain." FEDEA working paper 2002-03.

Borjas, G. (1994). “The Economics of Immigration.” Journal of Economic Literature 32: December 1994, p 1667-1717.

Borjas, G., Freeman, R., and Katz, L. (1996). "Searching for the effect of immigration on the labor market." American Economic Review, vol. 86 (May), pp. 246-51.

Card, D. (1990) "The Impact of the Mariel Boatlift on the Miami Labor Market." Industrial and Labor Relation Review, XLIII, 245-257.

Card, D. (2001). "Immigrant Inflows, Native Outflows, and the Local Market Impacts of Higher Immigration." Journal of Labor Economics, XIX, pp. 22-64.

Card, D. (2005). "Is the New Immigration Really So Bad?" The Economic Journal 115, pp. 300-323.

Card, D., DiNardo, J. (2000). "Do immigrant inflows lead to native outflows?" American Economic Review, vol. 90 (2), pp. 360-67.

Carrasco, R., Jimeno, J.F., and Ortega, A.C. (2007). "The Effect of Immigration on the Labor Market Performance of Native-Born Workers: Some Evidence for Spain." Journal of Population Economics, 2008.

Carrington, W., Detragiache, E., Vishwanath, T. (1996). "Migration with Endogenous Moving Costs," American Economic Review, American Economic Association, vol. 86(4).

Ciccone, A., Papaioannou (2007). "Human Capital, the Structure of Production, and Growth." The Review of Economics and Statistics (forthcoming).

Chiwswick, B., Hatton, T. (2003). "International Migration and the Integration of Labor Markets", in Michael Bordo, Alan Taylor and Jeffrey Williamson (eds.), Globalization in Historical Perspective. Cambridge, MA: NBER.

Dolado, J., Duce, R., Jimeno, J.F. (1998). "Los Efectos de la Inmigración sobre la Demanda Relativa de Trabajo Cualificado, vs. Poco Cualificado: Evidencia para España." Cuadernos Económicos del ICE (1998), vol 63, pp11-30.

Dolado, J., Felgueroso, F., and Jimeno, J.F. (1997). "The effects of minimum bargained wages on earnings: evidence from Spain.” European Economic Review 1997, 41.

Domingo, A., Martinez, R. (2006) "La población latinoamericana censada en España: un retrato sociodemográfico". Notas de Población, XXXII (81) , pp. 99-127. 
Dustmann, C., Glitz, A. (2007). "How Do Industries and Firms Respond to Changes in Local Labor Supply?" Preliminary draft.

Ethier, W. (1972). "Nontraded Goods and the Heckscher-Ohlin Model.” International Economic Review 13(1), pp. 132-147.

Facchini, G., Mayda, A., (2007). "Individual attitudes towards immigrants: Welfare-state determinants across countries." Review of Economics and Statistics, forthcoming.

Friedberg, R., and Hunt, J. (1995). "The Impact of Immigrants on Host Country Wages, Employment and Growth." Journal of Economic Persepctives 9(2): Spring 1995, p 23-44.

Gandal, N., Hanson, G., Slaughter, M. (2005). "Technology, trade, and adjustment to immigration in Israel". European Economic Review 48, 403-428.

Hanson, G., and Slaughter, M. (2002). "Labor-market adjustment in open economies: Evidence from US states." Journal of International Economics 57(1).

Leamer, E. (1995). The Heckscher-Ohlin Model in Theory and Practice. Princeton Studies in International Finance, vol 77. Princeton, NJ: International Finance Section, 1995.

Lewis, E. (2003). "Local, Open Economies Within the US: How Do Industries Respond to Immigration?" Federal Reserve Bank of Philadelphia Working Paper 04-01.

Lewis, E. (2005). "Immigration, Skill Mix, and the Choice of Technique.” Federal Reserve Bank of Philadelphia Working Paper 05-08.

Mayda, A., Rodrik, D., (2005) "Why are Some People (and Countries) More Protectionist than Others?." European Economic Review, August 2005, 49(6).

Mayda, A., (2006). "Who is against immigration? A cross-country investigation of individual attitudes toward immigrants." Review of Economics and Statistics, August 2006, 88(3).

Ottaviano, G., and Peri, G. (2006). "The Economic Value of Cultural Diversity: Evidence from U.S. cities." Journal of Economic Geography, Vol. 6, Issue 1, pp. 9-44.

Peri, G., and Sparber, C. (2007). Task Specialization, Comparative Advantages and the Effects of Immigration on Wages. Preliminary draft.

Recaño, J., (2004) "Las migraciones internas de retorno en España durante la primera mitad de la década de los noventa: implicaciones demográficas y territoriales". Scripta Nova, VIII.

Rybcszynski, T.M. (1955). "Factor endowments and relative commodity prices." Economica 22, 336-341.

Saiz, A. (2003). "Room in the Kitchen for the Melting Pot: Immigration and Rental Prices." Review of Economics and Statistics, 85, pp. 502-521.

Saiz, A. (2007). "Immigration and housing rents in American cities," Journal of Urban Economics, vol. 61(2), pp. 345-371.

Simón-Pérez, H. (2001). "Collective bargaining and wages." Revista del Ministerio de Trabajo y Asuntos Sociales: Economía y Sociología, 2001, 31. 


\section{Appendix 1: $\quad$ Figures}

Figure 1. Share of the foreign-born population (age 25-44) in Spain. Registry data at January $1^{\text {st }}$ of each year ("Padrón").

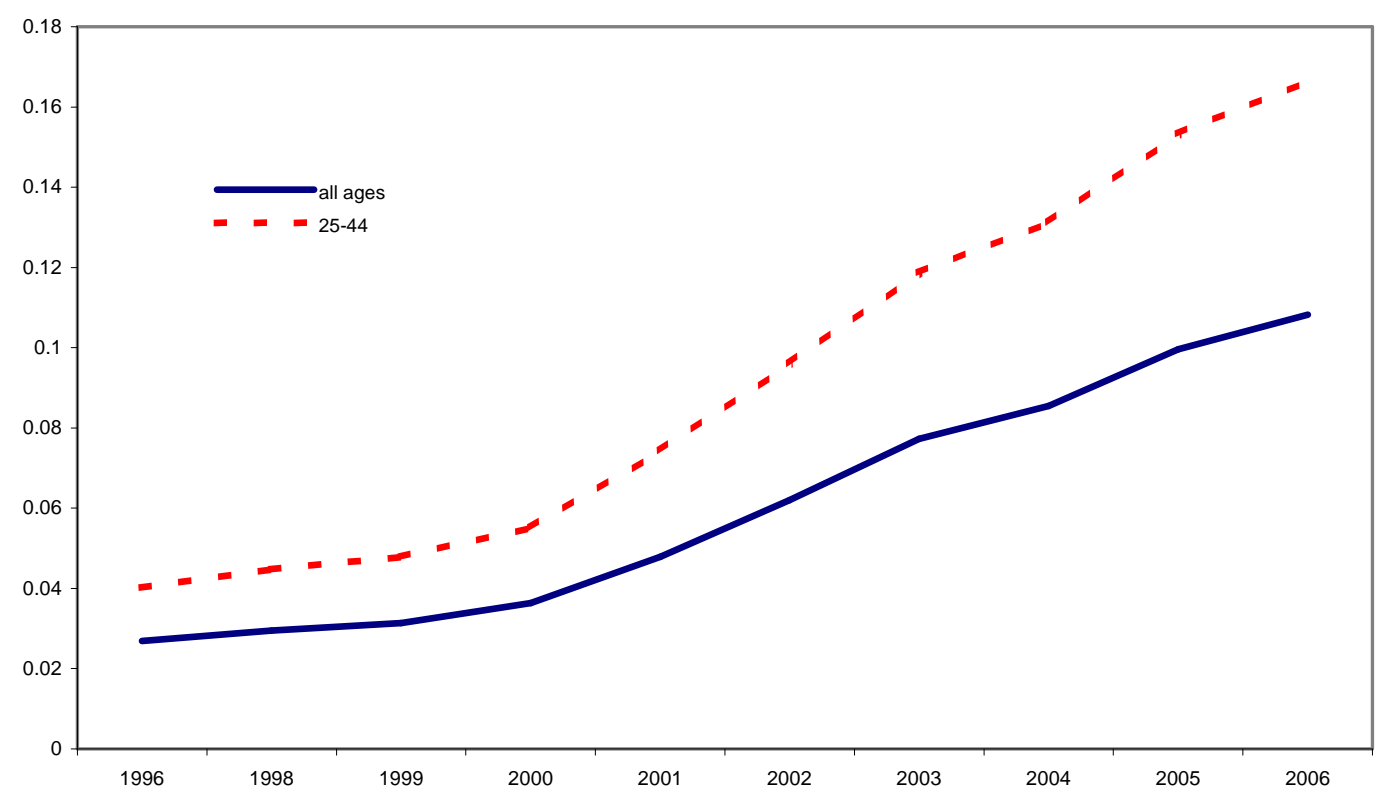

Figure 2. Foreign-born share in 2006 (age bracket 25-45) in Spanish provinces. Source: 2006 Spanish Labor Force Survey (EPA).

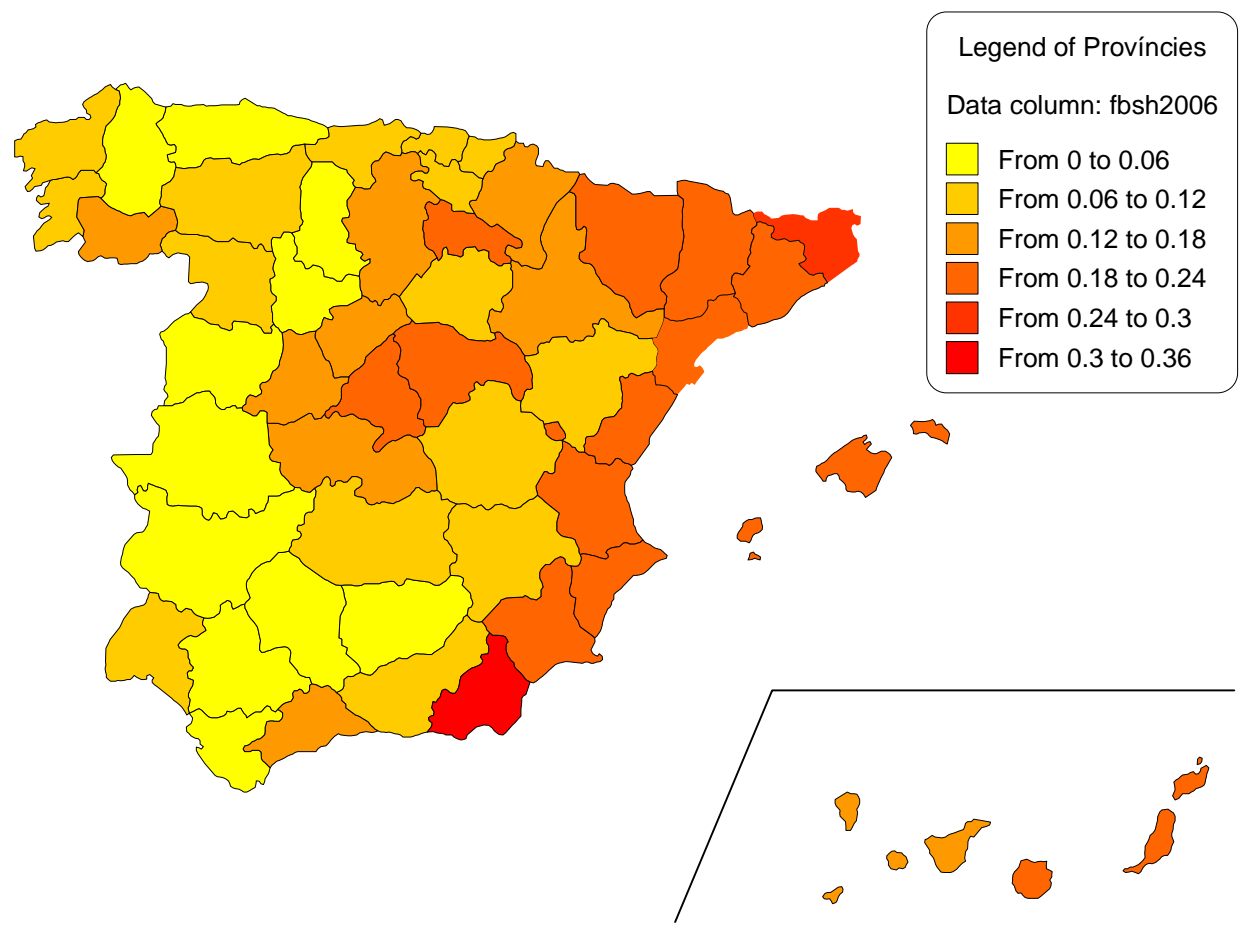




\section{Appendix 2: $\quad$ Tables}

Table 1. Descriptive statistics, 2001-2006.

\begin{tabular}{|c|c|c|c|c|c|}
\hline All skills & Obs & Mean & Std. Dev. & Min & $\operatorname{Max}$ \\
\hline$\Delta \mathrm{L}(\mathrm{r}) / \mathrm{L}(\mathrm{r} ; 2001)$ & 52 & 0.1015 & 0.1135 & -0.1076 & 0.4535 \\
\hline$M(r) / L(r ; 2001)$ & 52 & 0.0897 & 0.0705 & 0.0179 & 0.3827 \\
\hline$\Delta \mathrm{N}(\mathrm{r}) / \mathrm{N}(\mathrm{r} ; 2001)$ & 52 & 0.1929 & 0.1285 & -0.0655 & 0.546 \\
\hline High school dropouts & Obs & Mean & Std. Dev. & Min & $\operatorname{Max}$ \\
\hline$\Delta \mathrm{L}(\mathrm{e}, \mathrm{r}) / \mathrm{L}(\mathrm{e}, \mathrm{r} ; 2001)$ & 52 & -0.2918 & 0.4974 & -0.7597 & 2.3253 \\
\hline$M(e, r)$ & 52 & 5803 & 9925 & 0 & 52502 \\
\hline$M(e, r) / L(e, r ; 2001)$ & 52 & 0.1433 & 0.1712 & 0 & 0.9286 \\
\hline$Z(e, r)$ & 52 & 5803 & 10951 & 137 & 61569 \\
\hline $\mathrm{Z}(\mathrm{e}, \mathrm{r}) / \mathrm{L}(\mathrm{e}, \mathrm{r} ; 2001)$ & 52 & 0.1381 & 0.2284 & 0.0114 & 1.4811 \\
\hline$\Delta \mathrm{N}(\mathrm{e}, \mathrm{r}) / \mathrm{N}(\mathrm{e}, \mathrm{r} ; 2001)$ & 52 & -0.2045 & 0.7636 & -0.7752 & 4.4279 \\
\hline UE $(e, r)$ & 52 & -0.1537 & 0.1645 & -0.3366 & 0.5674 \\
\hline$B(e, r)$ & 52 & 0.1221 & 0.1096 & -0.1151 & 0.4442 \\
\hline$W(e, r)$ & 52 & -0.2304 & 0.2780 & -0.5548 & 1.2700 \\
\hline $\mathrm{l}(\mathrm{e}, \mathrm{r})$ & 52 & -0.0298 & 0.0810 & -0.2374 & 0.2731 \\
\hline High school graduates & Obs & Mean & Std. Dev. & Min & Max \\
\hline$\Delta \mathrm{L}(\mathrm{e}, \mathrm{r}) / \mathrm{L}(\mathrm{e}, \mathrm{r} ; 2001)$ & 52 & 0.2374 & 0.1872 & -0.0342 & 0.9870 \\
\hline$M(e, r)$ & 52 & 16895 & 29687 & 0 & 165135 \\
\hline$M(e, r) / L(e, r ; 2001)$ & 52 & 0.0898 & 0.0835 & 0.0000 & 0.4938 \\
\hline$Z(e, r)$ & 52 & 16895 & 32548 & 413 & 181903 \\
\hline Z(e,r)/L(e,r;2001) & 52 & 0.0916 & 0.0855 & 0.0125 & 0.4545 \\
\hline$\Delta \mathrm{N}(\mathrm{e}, \mathrm{r}) / \mathrm{N}(\mathrm{e}, \mathrm{r} ; 2001)$ & 52 & 0.3214 & 0.2167 & -0.0029 & 1.2167 \\
\hline $\mathrm{UE}(e, r)$ & 52 & 0.0129 & 0.0562 & -0.0779 & 0.2109 \\
\hline$B(e, r)$ & 52 & 0.1372 & 0.0955 & -0.1074 & 0.4187 \\
\hline$W(e, r)$ & 52 & 0.0737 & 0.0842 & -0.0801 & 0.3149 \\
\hline $\mathrm{I}(e, r)$ & 52 & 0.0137 & 0.0281 & -0.0418 & 0.1410 \\
\hline College graduates & Obs & Mean & Std. Dev. & Min & $\operatorname{Max}$ \\
\hline$\Delta \mathrm{L}(\mathrm{e}, \mathrm{r}) / \mathrm{L}(\mathrm{e}, \mathrm{r} ; 2001)$ & 52 & 0.2246 & 0.1947 & -0.2746 & 0.6600 \\
\hline$M(e, r)$ & 52 & 4824 & 9895 & 42 & 55692 \\
\hline$M(e, r) / L(e, r ; 2001)$ & 52 & 0.0735 & 0.0619 & 0.0060 & 0.3228 \\
\hline$Z(e, r)$ & 52 & 4824 & 8666 & 110 & 47849 \\
\hline Z(e,r)/L(e,r;2001) & 52 & 0.0807 & 0.0653 & 0.0137 & 0.2465 \\
\hline $\mathrm{DN}(e, r) / \mathrm{N}(\mathrm{e}, \mathrm{r} ; 2001)$ & 52 & 0.3083 & 0.2263 & -0.3015 & 0.9263 \\
\hline $\mathrm{UE}(e, r)$ & 52 & -0.0167 & 0.0506 & -0.1233 & 0.1252 \\
\hline$B(e, r)$ & 52 & 0.1524 & 0.1039 & -0.0621 & 0.4015 \\
\hline$W(e, r)$ & 52 & 0.0647 & 0.1071 & -0.2867 & 0.2784 \\
\hline $\mathrm{I}(\mathrm{e}, \mathrm{r})$ & 52 & 0.0242 & 0.0430 & -0.0913 & 0.1219 \\
\hline
\end{tabular}

Source: EPA 2001 and 2006 (all quarters) and 1991 Census. Individuals age 25-45. Changes refer to period 2001-2006. L(r), M(r) and N(r) are sums over all education groups. Respectively, they are the total population (natives and immigrants), the foreign-born that arrived in Spain in 2001-2006, and total employment, in each province " $r$ ". Z(e,r) are imputed immigration flows. UE(e,r), B(e,r), W(e,r), and $\mathrm{I}(\mathrm{e}, \mathrm{r})$ are the absorption through Unemployment, Between-industry, Within-industry, and the Interaction term defined in section 5 . 
Table 2a. Inflows of foreign-born workers in 2001-2006 relative to region's total population in 2001.

\begin{tabular}{|c|c|c|c|c|c|c|c|}
\hline $\begin{array}{l}\text { Quartile } \\
\text { means }\end{array}$ & $\begin{array}{c}1 \\
0.19 \\
\end{array}$ & & $\begin{array}{c}2 \\
0.10 \\
\end{array}$ & & $\begin{array}{c}3 \\
0.05 \\
\end{array}$ & & $\begin{array}{c}4 \\
0.02 \\
\end{array}$ \\
\hline Almeria & 0.38 & Valencia & 0.14 & Huesca & 0.07 & Ceuta & 0.03 \\
\hline Tarragona & 0.22 & Barcelona & 0.13 & Teruel & 0.07 & Cordoba & 0.03 \\
\hline Alicante & 0.19 & Zaragoza & 0.12 & Cantabria & 0.06 & Lugo & 0.03 \\
\hline Girona & 0.19 & Toledo & 0.12 & Alava & 0.05 & Melilla & 0.03 \\
\hline Segovia & 0.18 & Avila & 0.10 & Valladolid & 0.05 & Huelva & 0.03 \\
\hline Murcia & 0.18 & Granada & 0.10 & Corunya & 0.05 & Salamanca & 0.03 \\
\hline Castellon & 0.18 & Navarra & 0.09 & Vizcaya & 0.05 & Caceres & 0.02 \\
\hline Baleares & 0.16 & Albacete & 0.09 & Guipuzcoa & 0.05 & Leon & 0.02 \\
\hline Rioja & 0.15 & Malaga & 0.09 & Pontevedra & 0.04 & Badajoz & 0.02 \\
\hline Lleida & 0.15 & Soria & 0.09 & Cuenca & 0.04 & Cadiz & 0.02 \\
\hline Guadalajara & 0.15 & S.C. Tenerife & 0.08 & Asturias & 0.04 & Jaen & 0.02 \\
\hline Madrid & 0.14 & Ciudad Real & 0.08 & Zamora & 0.04 & Orense & 0.02 \\
\hline Palmas (Las) & 0.14 & Burgos & 0.07 & Sevilla & 0.04 & Palencia & 0.02 \\
\hline
\end{tabular}

Source: EPA 2006, all quarters. Population 25-45. Foreign-born individuals with less than 5 years of residence in Spain.

Table 2b. Changes in skill groups in 2001-2006.

\begin{tabular}{||l|c|c|c||}
\hline \hline & Low Imm. & Average & High Imm. \\
\hline All education groups & & & \\
$\Delta \mathrm{L}(\mathrm{r}) / \mathrm{L}(\mathrm{r} ; 2001)$ & 0.0254 & 0.1015 & 0.1775 \\
$\mathrm{M}(\mathrm{r}) / \mathrm{L}(\mathrm{r} ; 2001)$ & 0.0367 & 0.0897 & 0.1426 \\
\hline High school dropouts & & & \\
$\Delta \mathrm{L}(\mathrm{e}, \mathrm{r}) / \mathrm{L}(\mathrm{e}, \mathrm{r} ; 2001)$ & -0.5055 & -0.2917 & -0.078 \\
$\mathrm{M}(\mathrm{e}, \mathrm{r}) / \mathrm{L}(\mathrm{e}, \mathrm{r} ; 2001)$ & 0.0497 & 0.1433 & 0.2368 \\
\hline High school graduates & & & \\
$\Delta \mathrm{L}(\mathrm{e}, \mathrm{r}) / \mathrm{L}(\mathrm{e}, \mathrm{r} ; 2001)$ & 0.1901 & 0.2374 & 0.2848 \\
$\mathrm{M}(\mathrm{e}, \mathrm{r}) / \mathrm{L}(\mathrm{e}, \mathrm{r} ; 2001)$ & 0.0336 & 0.0898 & 0.146 \\
\hline College graduates & & & \\
$\Delta \mathrm{L}(\mathrm{e}, \mathrm{r}) / \mathrm{L}(\mathrm{e}, \mathrm{r} ; 2001)$ & 0.1743 & 0.2245 & 0.2748 \\
$\mathrm{M}(\mathrm{e}, \mathrm{r}) / \mathrm{L}(\mathrm{e}, \mathrm{r} ; 2001)$ & 0.0384 & 0.0735 & 0.1087 \\
\hline \hline
\end{tabular}

Note: High immigration regions are provinces with above-median immigration flows, measured by $\mathrm{M}(\mathrm{r}) / \mathrm{L}(\mathrm{r} ; 2001)$. Low immigration regions are below-median regions. 
Table 3. Actual and imputed immigration flows by education

\begin{tabular}{|c|c|c|c|c|c|c|c|c|}
\hline $\begin{array}{l}\text { Dep. var. } \\
\text { Explanatory var. }\end{array}$ & $\begin{array}{l}M(e, r) \\
Z(e, r)\end{array}$ & & & & $\begin{array}{l}\mathrm{M}(\mathrm{e}, \mathrm{r}) / \mathrm{L}(\mathrm{e}, \mathrm{r} ; \mathrm{z} \\
\mathrm{Z}(\mathrm{e}, \mathrm{r}) / \mathrm{L}(\mathrm{e}, \mathrm{r} ; 2\end{array}$ & 001) & & \\
\hline Country of origin & Coefficient & Stdev & obs. & R-sq & Coefficient & Stdev & obs. & R-sq \\
\hline All countries & 0.776 & {$[0.048]^{\star \star *}$} & 156 & 0.79 & 1.39 & {$[0.127]^{* * *}$} & 150 & 0.61 \\
\hline $\begin{array}{l}\text { Dep. var. } \\
\text { Explanatory var. }\end{array}$ & $\begin{array}{l}M(e, r, c) \\
Z(e, r, c)\end{array}$ & & & & $\begin{array}{l}\mathrm{M}(\mathrm{e}, \mathrm{r}, \mathrm{c}) / \mathrm{L}(\mathrm{e}, \mathrm{r} \\
\mathrm{Z}(\mathrm{e}, \mathrm{r}, \mathrm{c}) / \mathrm{L}(\mathrm{e}, \mathrm{r}\end{array}$ & ;2001) & & \\
\hline Country of origin & coeff. & Stdev & obs. & R-sq & coeff. & Stdev & obs. & R-sq \\
\hline France & 1.312 & {$[0.200]^{* * *}$} & 156 & 0.34 & 1.325 & {$[0.629]^{* *}$} & 150 & 0.08 \\
\hline Italy & 0.064 & [0.285] & 156 & 0.03 & 0.514 & [0.315] & 150 & 0.09 \\
\hline Portugal & -0.658 & {$[0.510]$} & 156 & 0.03 & 0.253 & {$[0.751]$} & 150 & 0.1 \\
\hline UK & 1.178 & {$[0.149]^{* * *}$} & 156 & 0.41 & 0.43 & {$[0.109]^{\star * *}$} & 150 & 0.24 \\
\hline Germany & 0.839 & {$[0.382]^{* *}$} & 156 & 0.07 & -0.032 & [0.319] & 150 & 0.03 \\
\hline Other EU-12 & 1.257 & {$[0.189]^{\star \star *}$} & 156 & 0.34 & 0.436 & {$[0.171]^{\star *}$} & 150 & 0.1 \\
\hline Other Europe & 0.627 & {$[0.099]^{\star \star \star}$} & 156 & 0.42 & 0.158 & {$[0.256]$} & 150 & 0.04 \\
\hline Morocco & 0.611 & {$[0.099]^{* * *}$} & 156 & 0.4 & 2.437 & {$[0.178]^{\star \star *}$} & 150 & 0.71 \\
\hline Other Africa & 0.308 & {$[0.110]^{\star * *}$} & 156 & 0.22 & 1.23 & {$[0.162]^{\star * *}$} & 150 & 0.47 \\
\hline USA & 0.607 & {$[0.213]^{* * *}$} & 156 & 0.1 & -0.016 & [0.425] & 150 & 0.02 \\
\hline Cuba & 1.013 & {$[0.169]^{\star * *}$} & 156 & 0.32 & 0.266 & {$[0.104]^{\star *}$} & 150 & 0.14 \\
\hline Argentina & 0.673 & {$[0.083]^{* * *}$} & 156 & 0.51 & 0.475 & {$[0.172]^{\star * *}$} & 150 & 0.17 \\
\hline Venezuela & 0.222 & {$[0.121]^{\star}$} & 156 & 0.11 & 0.065 & {$[0.080]$} & 150 & 0.15 \\
\hline Mexico or Canada & 1.801 & {$[0.099]^{* * *}$} & 156 & 0.78 & 0.01 & {$[0.075]$} & 150 & 0.16 \\
\hline Other C. Am. \& Carib. & 0.506 & {$[0.103]^{\star * *}$} & 156 & 0.29 & 0.927 & {$[0.193]^{\star * *}$} & 150 & 0.26 \\
\hline Other South America & 0.807 & {$[0.034]^{\star \star *}$} & 156 & 0.88 & 0.846 & {$[0.152]^{\star * *}$} & 150 & 0.33 \\
\hline Asia and Oceania & 1.259 & {$[0.217]^{\star * *}$} & 156 & 0.27 & 0.275 & {$[0.317]$} & 150 & 0.08 \\
\hline
\end{tabular}

Standard errors in brackets

* significant at $10 \%$; ${ }^{* *}$ significant at $5 \% ;{ }^{* * *}$ significant at $1 \%$

Note: The regressions in the right panel exclude outlier provinces (Ceuta and Melilla). 
Table 4. First-stage regressions

\begin{tabular}{|c|c|c|c|c|c|c|}
\hline Dep. Var. & $\mathrm{DL}(\mathrm{e}, \mathrm{r}) / \mathrm{L}(\mathrm{e}, \mathrm{r} ; 2001)$ & & & & & \\
\hline Explanatory Var. & $\mathrm{Z}(\mathrm{e}, \mathrm{r}) / \mathrm{L}(\mathrm{e}, \mathrm{r} ; 2001)$ & & & & & \\
\hline OLS & 1 & 2 & 3 & 4 & 5 & 6 \\
\hline$Z(e, r) / L(e, r ; 2001)$ & 0.474 & 1.178 & 4.634 & 3.631 & 4.634 & 3.631 \\
\hline stdev. & {$[0.178]^{\star \star \star}$} & {$[0.266]^{\star * *}$} & {$[0.456]^{\star \star *}$} & {$[0.497]^{\star \star *}$} & {$[0.630]^{\star \star \star}$} & {$[0.962]^{\star * *}$} \\
\hline tstat. & 2.7 & 4.43 & 10.15 & 7.31 & 7.35 & 3.77 \\
\hline Constant & -0.357 & -0.454 & -0.761 & -0.743 & -0.761 & -0.743 \\
\hline stdev. & {$[0.051]^{\star * *}$} & {$[0.055]^{* * *}$} & {$[0.056]^{* * *}$} & {$[0.062]^{\star * *}$} & {$[0.069]^{\star \star \star}$} & {$[0.101]^{* * *}$} \\
\hline High school graduates & 0.551 & 0.584 & 0.632 & 0.651 & 0.632 & 0.651 \\
\hline stdev. & {$[0.063]^{\star \star \star}$} & {$[0.060]^{\star * *}$} & {$[0.047]^{\star \star *}$} & {$[0.041]^{* \star *}$} & {$[0.045]^{\star \star \star}$} & {$[0.040]^{\star * *}$} \\
\hline College graduates & 0.544 & 0.584 & 0.641 & 0.701 & 0.641 & 0.701 \\
\hline stdev. & {$[0.064]^{\star * *}$} & {$[0.061]^{* * *}$} & {$[0.047]^{\star * *}$} & {$[0.047]^{\star * *}$} & {$[0.050]^{\star \star *}$} & {$[0.047]^{* * *}$} \\
\hline Region f-e & $\mathrm{N}$ & $Y$ & Y & Y & $\mathbf{Y}$ & $\mathrm{Y}$ \\
\hline Drop outliers & $\mathrm{N}$ & $\mathrm{N}$ & $\mathrm{Y}$ & Y & $\mathbf{Y}$ & $\mathrm{Y}$ \\
\hline Weights & $\mathrm{N}$ & $\mathrm{N}$ & $\mathrm{N}$ & Y & $\mathbf{N}$ & $\mathrm{Y}$ \\
\hline Robust & $\mathrm{N}$ & $\mathrm{N}$ & $\mathrm{N}$ & $\mathrm{N}$ & $\mathbf{Y}$ & $\mathrm{Y}$ \\
\hline Observations & 156 & 156 & 150 & 150 & 150 & 150 \\
\hline R-squared & 0.4 & 0.65 & 0.8 & 0.79 & 0.8 & 0.79 \\
\hline
\end{tabular}

Standard errors in brackets

${ }^{*}$ significant at $10 \%$; ${ }^{* *}$ significant at $5 \%$; ${ }^{* *}$ significant at $1 \%$

Note: Outliers are education-province observations for Ceuta and Melilla (6 obs.). The regression includes education dummies. 


\section{Table 5. Increase in Aggregate Employment}

\begin{tabular}{|c|c|c|c|c|c|c|}
\hline \multirow[t]{2}{*}{ Dependent variable } & \multicolumn{6}{|c|}{$\Delta \mathrm{N}(\mathrm{e}, \mathrm{r}) / \mathrm{N}(\mathrm{e}, \mathrm{r} ; 2001)$ weighted } \\
\hline & 1 & 2 & 3 & 4 & 5 & 6 \\
\hline \multicolumn{7}{|l|}{ OLS } \\
\hline$\Delta \mathrm{L}(\mathrm{e}, \mathrm{r}) / \mathrm{L}(\mathrm{e}, \mathrm{r} ; 2001)$ & 0.728 & 0.728 & 0.731 & 0.726 & 0.731 & 0.726 \\
\hline stdev. & {$[0.014]^{* * *}$} & {$[0.016]^{* * *}$} & {$[0.015]^{* * *}$} & {$[0.019]^{\star * *}$} & {$[0.015]^{\star \star *}$} & {$[0.020]^{\star * *}$} \\
\hline \multicolumn{7}{|l|}{ IV } \\
\hline$\Delta \mathrm{L}(\mathrm{e}, \mathrm{r}) / \mathrm{L}(\mathrm{e}, \mathrm{r} ; 2001)$ & 0.619 & 0.733 & 0.728 & 0.73 & 0.728 & 0.73 \\
\hline stdev. & {$[0.077]^{\star * *}$} & {$[0.039]^{* * *}$} & {$[0.021]^{\star * *}$} & {$[0.032]^{* * *}$} & {$[0.015]^{\star \star \star}$} & {$[0.029]^{* * *}$} \\
\hline Constant & 0.043 & 0.065 & 0.064 & 0.075 & 0.064 & 0.075 \\
\hline stdev. & {$[0.024]^{*}$} & {$[0.034]^{*}$} & {$[0.031]^{\star *}$} & {$[0.036]^{\star *}$} & {$[0.012]^{\star \star \star}$} & {$[0.018]^{\star * \star}$} \\
\hline High school graduates & 0.035 & -0.025 & -0.026 & -0.034 & -0.026 & -0.034 \\
\hline stdev. & {$[0.043]$} & {$[0.023]$} & {$[0.015]^{*}$} & {$[0.021]$} & {$[0.012]^{\star \star}$} & {$[0.020]^{*}$} \\
\hline College graduates & 0.06 & 0.001 & 0.003 & -0.007 & 0.003 & -0.007 \\
\hline stdev. & {$[0.042]$} & {$[0.022]$} & {$[0.015]$} & {$[0.022]$} & {$[0.012]$} & [0.022] \\
\hline Region f-e & $\mathrm{N}$ & Y & Y & Y & $\mathbf{Y}$ & Y \\
\hline Drop outliers & $\mathrm{N}$ & $\mathrm{N}$ & Y & $\mathrm{Y}$ & $\mathbf{Y}$ & Y \\
\hline Weights & $\mathrm{N}$ & $\mathrm{N}$ & $\mathrm{N}$ & $\mathrm{Y}$ & $\mathbf{N}$ & Y \\
\hline Robust & $\mathrm{N}$ & $\mathrm{N}$ & $\mathrm{N}$ & $\mathrm{N}$ & $\mathbf{Y}$ & $\mathrm{Y}$ \\
\hline Observations & 156 & 156 & 150 & 150 & 150 & 150 \\
\hline R-squared & 0.95 & 0.98 & 0.98 & 0.98 & 0.98 & 0.98 \\
\hline
\end{tabular}

Standard errors in brackets

* significant at $10 \%$; ** significant at $5 \%$; *** significant at $1 \%$

Note: Outliers are education-province observations for Ceuta and Melilla (6 obs.). The regression includes education dummies. 
Table 6a. Between-industry adjustment (16 industries)

\begin{tabular}{|c|c|c|c|c|c|c|}
\hline \multirow[t]{2}{*}{ Dependent variable } & \multicolumn{6}{|c|}{$\mathrm{BE}(\mathrm{e}, \mathrm{r})$} \\
\hline & 1 & 2 & 3 & 4 & 5 & 6 \\
\hline \multicolumn{7}{|c|}{ OLS - All industries (16) } \\
\hline $\begin{array}{l}\Delta \mathrm{L}(\mathrm{e}, \mathrm{r}) / \mathrm{L}(\mathrm{e}, \mathrm{r} ; 2001) \\
\text { stdev. }\end{array}$ & $\begin{array}{c}0.141 \\
{[0.023]^{* * *}}\end{array}$ & $\begin{array}{c}0.052 \\
{[0.018]^{* * *}}\end{array}$ & $\begin{array}{c}0.049 \\
{[0.018]^{* * *}}\end{array}$ & $\begin{array}{c}0.063 \\
{[0.019]^{* * *}}\end{array}$ & $\begin{array}{c}0.049 \\
{[0.024]^{\star *}}\end{array}$ & $\begin{array}{c}0.063 \\
{[0.024]^{* *}}\end{array}$ \\
\hline \multicolumn{7}{|l|}{ IV - All industries (16) } \\
\hline $\begin{array}{l}\Delta \mathrm{L}(\mathrm{e}, \mathrm{r}) / \mathrm{L}(\mathrm{e}, \mathrm{r} ; 2001) \\
\text { stdev. }\end{array}$ & $\begin{array}{l}-0.178 \\
{[0.163]}\end{array}$ & $\begin{array}{c}0.016 \\
{[0.044]}\end{array}$ & $\begin{array}{c}0.034 \\
{[0.025]}\end{array}$ & $\begin{array}{c}0.061 \\
{[0.031]^{*}}\end{array}$ & $\begin{array}{c}0.034 \\
{[0.027]}\end{array}$ & $\begin{array}{c}0.061 \\
{[0.036]^{*}}\end{array}$ \\
\hline $\begin{array}{l}\text { Constant } \\
\text { stdev. }\end{array}$ & $\begin{array}{c}0.07 \\
{[0.051]}\end{array}$ & $\begin{array}{c}0.132 \\
{[0.039]^{\star * *}}\end{array}$ & $\begin{array}{c}0.139 \\
{[0.035]^{\star * *}}\end{array}$ & $\begin{array}{c}0.149 \\
{[0.036]^{* * *}}\end{array}$ & $\begin{array}{c}0.139 \\
{[0.017]^{\star \star \star}}\end{array}$ & $\begin{array}{c}0.149 \\
{[0.018]^{* * *}}\end{array}$ \\
\hline $\begin{array}{l}\text { High school graduates } \\
\text { stdev. }\end{array}$ & $\begin{array}{c}0.109 \\
{[0.091]}\end{array}$ & $\begin{array}{c}0.007 \\
{[0.026]}\end{array}$ & $\begin{array}{l}-0.001 \\
{[0.018]}\end{array}$ & $\begin{array}{l}-0.015 \\
{[0.021]}\end{array}$ & $\begin{array}{c}-0.001 \\
{[0.017]}\end{array}$ & $\begin{array}{l}-0.015 \\
{[0.023]}\end{array}$ \\
\hline $\begin{array}{l}\text { College graduates } \\
\text { stdev. }\end{array}$ & $\begin{array}{c}0.122 \\
{[0.089]}\end{array}$ & $\begin{array}{c}0.022 \\
{[0.026]}\end{array}$ & $\begin{array}{c}0.012 \\
{[0.017]}\end{array}$ & $\begin{array}{c}-0.004 \\
{[0.022]}\end{array}$ & $\begin{array}{c}0.012 \\
{[0.019]}\end{array}$ & $\begin{array}{c}-0.004 \\
{[0.023]}\end{array}$ \\
\hline Region f-e & $\mathrm{N}$ & $\mathrm{Y}$ & $\mathrm{Y}$ & $\mathrm{Y}$ & $\mathbf{Y}$ & $\mathrm{Y}$ \\
\hline Drop outliers & $\mathrm{N}$ & $\mathrm{N}$ & $\mathrm{Y}$ & $\mathrm{Y}$ & $\mathbf{Y}$ & Y \\
\hline Weights & $\mathrm{N}$ & $\mathrm{N}$ & $\mathrm{N}$ & $\mathrm{Y}$ & $\mathbf{N}$ & Y \\
\hline Robust & $\mathrm{N}$ & $\mathrm{N}$ & $\mathrm{N}$ & $\mathrm{N}$ & $\mathbf{Y}$ & $\mathrm{Y}$ \\
\hline Observations & 156 & 156 & 150 & 150 & 150 & 150 \\
\hline R-squared & & 0.79 & 0.79 & 0.83 & 0.79 & 0.79 \\
\hline \multicolumn{7}{|l|}{ OLS - Only traded } \\
\hline $\begin{array}{l}\Delta \mathrm{L}(\mathrm{e}, \mathrm{r}) / \mathrm{L}(\mathrm{e}, \mathrm{r} ; 2001) \\
\text { stdev. }\end{array}$ & $\begin{array}{c}0.03 \\
{[0.010]^{\star * *}}\end{array}$ & $\begin{array}{c}0.006 \\
{[0.007]}\end{array}$ & $\begin{array}{c}0.004 \\
{[0.007]}\end{array}$ & $\begin{array}{c}0.006 \\
{[0.008]}\end{array}$ & $\begin{array}{c}0.004 \\
{[0.006]}\end{array}$ & $\begin{array}{c}0.006 \\
{[0.006]}\end{array}$ \\
\hline \multicolumn{7}{|l|}{ IV - Only traded } \\
\hline $\begin{array}{l}\Delta \mathrm{L}(\mathrm{e}, \mathrm{r}) / \mathrm{L}(\mathrm{e}, \mathrm{r} ; 2001) \\
\text { stdev. }\end{array}$ & $\begin{array}{c}-0.092 \\
{[0.065]}\end{array}$ & $\begin{array}{c}0.03 \\
{[0.019]}\end{array}$ & $\begin{array}{c}0.008 \\
{[0.010]}\end{array}$ & $\begin{array}{c}0.011 \\
{[0.014]}\end{array}$ & $\begin{array}{c}0.008 \\
{[0.009]}\end{array}$ & $\begin{array}{c}0.011 \\
{[0.012]}\end{array}$ \\
\hline
\end{tabular}

Standard errors in brackets

${ }^{*}$ significant at $10 \%$; ** significant at $5 \%$; ${ }^{* * *}$ significant at $1 \%$

Note: Outliers are education-province observations for Ceuta and Melilla (6 obs.). The regression includes education dummies. 
Table 6b. Between-industry adjustment (30 industries)

\begin{tabular}{|c|c|c|c|c|c|c|}
\hline \multirow[t]{2}{*}{ Dependent variable } & \multicolumn{6}{|l|}{$\mathrm{BE}(e, r)$} \\
\hline & 1 & 2 & 3 & 4 & 5 & 6 \\
\hline \multicolumn{7}{|c|}{ OLS - All industries (30) } \\
\hline $\begin{array}{l}\Delta \mathrm{L}(\mathrm{e}, \mathrm{r}) / \mathrm{L}(\mathrm{e}, \mathrm{r} ; 2001) \\
\text { stdev. }\end{array}$ & $\begin{array}{c}0.15 \\
{[0.023]^{\star * *}}\end{array}$ & $\begin{array}{c}0.062 \\
{[0.019]^{\star * *}}\end{array}$ & $\begin{array}{c}0.059 \\
{[0.019]^{\star \star \star}}\end{array}$ & $\begin{array}{c}0.073 \\
{[0.020]^{\star * *}}\end{array}$ & $\begin{array}{c}0.059 \\
{[0.026]^{\star \star}}\end{array}$ & $\begin{array}{c}0.073 \\
{[0.027]^{\star \star \star}}\end{array}$ \\
\hline \multicolumn{7}{|c|}{ IV - All industries (30) } \\
\hline $\begin{array}{l}\Delta \mathrm{L}(\mathrm{e}, \mathrm{r}) / \mathrm{L}(\mathrm{e}, \mathrm{r} ; 2001) \\
\text { stdev. }\end{array}$ & $\begin{array}{l}-0.179 \\
{[0.167]}\end{array}$ & $\begin{array}{c}0.024 \\
{[0.047]}\end{array}$ & $\begin{array}{c}0.037 \\
{[0.026]}\end{array}$ & $\begin{array}{c}0.063 \\
{[0.033]^{*}}\end{array}$ & $\begin{array}{c}0.037 \\
{[0.027]}\end{array}$ & $\begin{array}{c}0.063 \\
{[0.036]^{*}}\end{array}$ \\
\hline $\begin{array}{l}\text { Constant } \\
\text { stdev. }\end{array}$ & $\begin{array}{c}0.068 \\
{[0.053]}\end{array}$ & $\begin{array}{c}0.144 \\
{[0.042]^{\star * *}}\end{array}$ & $\begin{array}{c}0.149 \\
{[0.038]^{* * *}}\end{array}$ & $\begin{array}{c}0.152 \\
{[0.038]^{\star * *}}\end{array}$ & $\begin{array}{c}0.149 \\
{[0.018]^{\star \star *}}\end{array}$ & $\begin{array}{c}0.152 \\
{[0.022]^{\star * *}}\end{array}$ \\
\hline $\begin{array}{l}\text { High school graduates } \\
\text { stdev. }\end{array}$ & $\begin{array}{c}0.111 \\
{[0.093]}\end{array}$ & $\begin{array}{c}0.004 \\
{[0.028]}\end{array}$ & $\begin{array}{l}-0.001 \\
{[0.019]}\end{array}$ & $\begin{array}{l}-0.014 \\
{[0.022]}\end{array}$ & $\begin{array}{l}-0.001 \\
{[0.017]}\end{array}$ & $\begin{array}{l}-0.014 \\
{[0.023]}\end{array}$ \\
\hline $\begin{array}{l}\text { College graduates } \\
\text { stdev. }\end{array}$ & $\begin{array}{c}0.124 \\
{[0.091]}\end{array}$ & $\begin{array}{c}0.02 \\
{[0.027]}\end{array}$ & $\begin{array}{c}0.013 \\
{[0.019]}\end{array}$ & $\begin{array}{l}-0.001 \\
{[0.023]}\end{array}$ & $\begin{array}{c}0.013 \\
{[0.020]}\end{array}$ & $\begin{array}{l}-0.001 \\
{[0.024]}\end{array}$ \\
\hline Region f-e & $\mathrm{N}$ & $\mathrm{Y}$ & $\mathrm{Y}$ & $\mathrm{Y}$ & $Y$ & $\mathrm{Y}$ \\
\hline Drop outliers & $\mathrm{N}$ & $\mathrm{N}$ & $\mathrm{Y}$ & $\mathrm{Y}$ & $\mathbf{Y}$ & $\mathrm{Y}$ \\
\hline Weights & $\mathrm{N}$ & $\mathrm{N}$ & $\mathrm{N}$ & $\mathrm{Y}$ & $\mathbf{N}$ & Y \\
\hline Robust & $\mathrm{N}$ & $\mathrm{N}$ & $\mathrm{N}$ & $\mathrm{N}$ & $\mathbf{Y}$ & $\mathrm{Y}$ \\
\hline Observations & 156 & 156 & 150 & 150 & 150 & 150 \\
\hline R-squared & 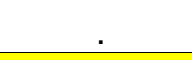 & 0.77 & 0.76 & 0.81 & 0.76 & 0.76 \\
\hline \multicolumn{7}{|l|}{ OLS - Only traded } \\
\hline $\begin{array}{l}\Delta \mathrm{L}(\mathrm{e}, \mathrm{r}) / \mathrm{L}(\mathrm{e}, \mathrm{r} ; 2001) \\
\text { stdev. }\end{array}$ & $\begin{array}{c}0.041 \\
{[0.010]^{\star \star \star}}\end{array}$ & $\begin{array}{c}0.018 \\
{[0.009]^{\star *}}\end{array}$ & $\begin{array}{c}0.016 \\
{[0.009]^{*}}\end{array}$ & $\begin{array}{c}0.019 \\
{[0.010]^{\star}}\end{array}$ & $\begin{array}{c}0.016 \\
{[0.009]^{*}}\end{array}$ & $\begin{array}{c}0.019 \\
{[0.009]^{\star *}}\end{array}$ \\
\hline \multicolumn{7}{|l|}{ IV - Only traded } \\
\hline $\begin{array}{l}\Delta \mathrm{L}(\mathrm{e}, \mathrm{r}) / \mathrm{L}(\mathrm{e}, \mathrm{r} ; 2001) \\
\text { stdev. }\end{array}$ & $\begin{array}{l}-0.086 \\
{[0.069]}\end{array}$ & $\begin{array}{c}0.039 \\
{[0.022]^{*}}\end{array}$ & $\begin{array}{c}0.013 \\
{[0.012]}\end{array}$ & $\begin{array}{c}0.018 \\
{[0.016]}\end{array}$ & $\begin{array}{c}0.013 \\
{[0.011]}\end{array}$ & $\begin{array}{c}0.018 \\
{[0.014]}\end{array}$ \\
\hline
\end{tabular}

Standard errors in brackets

${ }^{*}$ significant at $10 \%$; ** significant at $5 \% ;{ }^{* * *}$ significant at $1 \%$

Note: Outliers are education-province observations for Ceuta and Melilla (6 obs.). The regression includes education dummies. 
Table 7a. Within-industry adjustment (16 industries)

\begin{tabular}{|c|c|c|c|c|c|c|}
\hline \multirow[t]{2}{*}{ Dependent variable } & \multicolumn{6}{|l|}{$W E(e, r)$} \\
\hline & 1 & 2 & 3 & 4 & 5 & 6 \\
\hline \multicolumn{7}{|c|}{ OLS - All industries (16) } \\
\hline $\begin{array}{l}\Delta \mathrm{L}(\mathrm{e}, \mathrm{r}) / \mathrm{L}(\mathrm{e}, \mathrm{r} ; 2001) \\
\text { stdev. }\end{array}$ & $\begin{array}{c}0.491 \\
{[0.020]^{\star * *}}\end{array}$ & $\begin{array}{c}0.567 \\
{[0.019]^{\star * *}}\end{array}$ & $\begin{array}{c}0.568 \\
{[0.019]^{\star * *}}\end{array}$ & $\begin{array}{c}0.545 \\
{[0.022]^{\star * *}}\end{array}$ & $\begin{array}{c}0.568 \\
{[0.023]^{\star \star *}}\end{array}$ & $\begin{array}{c}0.545 \\
{[0.025]^{\star * *}}\end{array}$ \\
\hline \multicolumn{7}{|c|}{ IV - All industries (16) } \\
\hline $\begin{array}{l}\Delta \mathrm{L}(\mathrm{e}, \mathrm{r}) / \mathrm{L}(\mathrm{e}, \mathrm{r} ; 2001) \\
\text { stdev. }\end{array}$ & $\begin{array}{c}0.601 \\
{[0.101]^{\star * *}}\end{array}$ & $\begin{array}{c}0.576 \\
{[0.048]^{* * *}}\end{array}$ & $\begin{array}{c}0.586 \\
{[0.027]^{\star * *}}\end{array}$ & $\begin{array}{c}0.554 \\
{[0.037]^{\star * *}}\end{array}$ & $\begin{array}{c}0.586 \\
{[0.025]^{\star * *}}\end{array}$ & $\begin{array}{c}0.554 \\
{[0.036]^{* * *}}\end{array}$ \\
\hline $\begin{array}{l}\text { Constant } \\
\text { stdev. }\end{array}$ & $\begin{array}{c}-0.055 \\
{[0.032]^{\star}}\end{array}$ & $\begin{array}{c}-0.076 \\
{[0.042]^{*}}\end{array}$ & $\begin{array}{c}-0.07 \\
{[0.038]^{*}}\end{array}$ & $\begin{array}{l}-0.069 \\
{[0.042]}\end{array}$ & $\begin{array}{c}-0.07 \\
{[0.014]^{\star \star \star}}\end{array}$ & $\begin{array}{c}-0.069 \\
{[0.021]^{\star \star *}}\end{array}$ \\
\hline $\begin{array}{l}\text { High school graduates } \\
\text { stdev. }\end{array}$ & $\begin{array}{l}-0.014 \\
{[0.056]}\end{array}$ & $\begin{array}{l}-0.001 \\
{[0.028]}\end{array}$ & $\begin{array}{l}-0.012 \\
{[0.019]}\end{array}$ & $\begin{array}{l}-0.007 \\
{[0.024]}\end{array}$ & $\begin{array}{c}-0.012 \\
{[0.016]}\end{array}$ & $\begin{array}{l}-0.007 \\
{[0.022]}\end{array}$ \\
\hline $\begin{array}{l}\text { College graduates } \\
\text { stdev. }\end{array}$ & $\begin{array}{l}-0.015 \\
{[0.055]}\end{array}$ & $\begin{array}{l}-0.003 \\
{[0.028]}\end{array}$ & $\begin{array}{l}-0.007 \\
{[0.019]}\end{array}$ & $\begin{array}{c}0.001 \\
{[0.025]}\end{array}$ & $\begin{array}{l}-0.007 \\
{[0.017]}\end{array}$ & $\begin{array}{c}0.001 \\
{[0.022]}\end{array}$ \\
\hline \multicolumn{7}{|l|}{ OLS - Only traded } \\
\hline $\begin{array}{l}\Delta \mathrm{L}(\mathrm{e}, \mathrm{r}) / \mathrm{L}(\mathrm{e}, \mathrm{r} ; 2001) \\
\text { stdev. }\end{array}$ & $\begin{array}{c}0.252 \\
{[0.014]^{\star \star \star}}\end{array}$ & $\begin{array}{c}0.278 \\
{[0.018]^{\star \star \star}}\end{array}$ & $\begin{array}{c}0.281 \\
{[0.019]^{\star \star \star}}\end{array}$ & $\begin{array}{c}0.253 \\
{[0.020]^{\star \star *}}\end{array}$ & $\begin{array}{c}0.281 \\
{[0.027]^{\star \star \star}}\end{array}$ & $\begin{array}{c}0.253 \\
{[0.028]^{\star * \star}}\end{array}$ \\
\hline \multicolumn{7}{|l|}{ IV - Only traded } \\
\hline $\begin{array}{l}\Delta \mathrm{L}(\mathrm{e}, \mathrm{r}) / \mathrm{L}(\mathrm{e}, \mathrm{r} ; 2001) \\
\text { stdev. }\end{array}$ & $\begin{array}{c}0.347 \\
{[0.078]^{\star \star \star}}\end{array}$ & $\begin{array}{c}0.299 \\
{[0.046]^{\star * *}}\end{array}$ & $\begin{array}{c}0.309 \\
{[0.027]^{\star \star \star}}\end{array}$ & $\begin{array}{c}0.264 \\
{[0.033]^{\star \star \star}}\end{array}$ & $\begin{array}{c}0.309 \\
{[0.030]^{\star \star \star}}\end{array}$ & $\begin{array}{c}0.264 \\
{[0.047]^{\star \star \star}}\end{array}$ \\
\hline Region f-e & $\mathrm{N}$ & $\mathrm{Y}$ & $\mathrm{Y}$ & $\mathrm{Y}$ & $\mathbf{Y}$ & $Y$ \\
\hline Drop outliers & $\mathrm{N}$ & $\mathrm{N}$ & Y & Y & $\mathbf{Y}$ & Y \\
\hline Weights & $\mathrm{N}$ & $\mathrm{N}$ & $\mathrm{N}$ & Y & $\mathbf{N}$ & Y \\
\hline Robust & $\mathrm{N}$ & $\mathrm{N}$ & $\mathrm{N}$ & $\mathrm{N}$ & $\mathbf{Y}$ & $\mathrm{Y}$ \\
\hline Observations & 156 & 156 & 150 & 150 & 150 & 150 \\
\hline R-squared & 0.86 & 0.95 & 0.95 & 0.95 & 0.95 & 0.95 \\
\hline
\end{tabular}

Standard errors in brackets

* significant at $10 \%$; ** significant at $5 \%$; ${ }^{* * *}$ significant at $1 \%$

Note: Outliers are education-province observations for Ceuta and Melilla (6 obs.). The regression includes education dummies. 
Table $7 b . \quad$ Within-industry adjustment (30 industries)

Dependent variable $\mathrm{WE}(\mathrm{e}, \mathrm{r})$

\begin{tabular}{|c|c|c|c|c|c|c|}
\hline & 1 & 2 & 3 & 4 & 5 & 6 \\
\hline \multicolumn{7}{|l|}{ OLS - All industries (30) } \\
\hline$\Delta \mathrm{L}(\mathrm{e}, \mathrm{r}) / \mathrm{L}(\mathrm{e}, \mathrm{r} ; 2001)$ & 0.38 & 0.454 & 0.452 & 0.471 & 0.452 & 0.471 \\
\hline stdev. & {$[0.018]^{* * *}$} & {$[0.020]^{\star * *}$} & {$[0.020]^{* * *}$} & {$[0.022]^{\star * *}$} & {$[0.040]^{\star \star \star}$} & {$[0.041]^{\star * *}$} \\
\hline \multicolumn{7}{|l|}{ IV - All industries (30) } \\
\hline$\Delta \mathrm{L}(\mathrm{e}, \mathrm{r}) / \mathrm{L}(\mathrm{e}, \mathrm{r} ; 2001)$ & 0.458 & 0.449 & 0.408 & 0.433 & 0.408 & 0.433 \\
\hline stdev. & {$[0.090]^{* * *}$} & {$[0.049]^{\star * *}$} & {$[0.028]^{* * *}$} & {$[0.038]^{\star \star *}$} & {$[0.044]^{\star \star \star}$} & {$[0.061]^{\star * *}$} \\
\hline Constant & -0.115 & -0.145 & -0.162 & -0.131 & -0.162 & -0.131 \\
\hline stdev. & {$[0.028]^{* * *}$} & {$[0.043]^{* * *}$} & {$[0.041]^{\star * *}$} & {$[0.043]^{* * *}$} & {$[0.035]^{\star \star \star}$} & {$[0.037]^{\star * *}$} \\
\hline High school graduates & 0.08 & 0.085 & 0.104 & 0.072 & 0.104 & 0.072 \\
\hline stdev. & {$[0.050]$} & {$[0.029]^{\star * *}$} & {$[0.020]^{\star \star *}$} & {$[0.025]^{\star \star *}$} & {$[0.029]^{\star \star \star}$} & {$[0.039]^{*}$} \\
\hline College graduates & 0.064 & 0.068 & 0.093 & 0.072 & 0.093 & 0.072 \\
\hline stdev. & {$[0.049]$} & {$[0.028]^{\star *}$} & {$[0.020]^{\star * *}$} & {$[0.026]^{\star * *}$} & {$[0.028]^{\star \star \star}$} & {$[0.040]^{*}$} \\
\hline \multicolumn{7}{|l|}{ OLS - Only traded } \\
\hline$\Delta \mathrm{L}(\mathrm{e}, \mathrm{r}) / \mathrm{L}(\mathrm{e}, \mathrm{r} ; 2001)$ & 0.156 & 0.18 & 0.18 & 0.188 & 0.18 & 0.188 \\
\hline stdev. & {$[0.013]^{\star \star *}$} & {$[0.017]^{\star * *}$} & {$[0.018]^{\star * *}$} & {$[0.019]^{\star \star *}$} & {$[0.024]^{\star \star \star}$} & {$[0.023]^{\star * *}$} \\
\hline \multicolumn{7}{|l|}{ IV - Only traded } \\
\hline$\Delta \mathrm{L}(\mathrm{e}, \mathrm{r}) / \mathrm{L}(\mathrm{e}, \mathrm{r} ; 2001)$ & 0.219 & 0.187 & 0.157 & 0.159 & 0.157 & 0.157 \\
\hline stdev. & {$[0.065]^{\star \star *}$} & {$[0.043]^{\star \star \star}$} & {$[0.025]^{\star \star *}$} & {$[0.032]^{\star * *}$} & {$[0.025]^{\star \star \star}$} & {$[0.025]^{\star * *}$} \\
\hline Region f-e & $\mathrm{N}$ & $Y$ & $Y$ & $Y$ & $Y$ & $\mathrm{Y}$ \\
\hline Drop outliers & $\mathrm{N}$ & $\mathrm{N}$ & $Y$ & $Y$ & $\mathbf{Y}$ & Y \\
\hline Weights & $\mathrm{N}$ & $\mathrm{N}$ & $\mathrm{N}$ & $Y$ & $\mathbf{N}$ & Y \\
\hline Robust & $\mathrm{N}$ & $\mathrm{N}$ & $\mathrm{N}$ & $\mathrm{N}$ & $\mathbf{Y}$ & $Y$ \\
\hline Observations & 156 & 156 & 150 & 150 & 150 & 150 \\
\hline R-squared & 0.86 & 0.93 & 0.93 & 0.94 & 0.93 & 0.93 \\
\hline
\end{tabular}

Standard errors in brackets

* significant at $10 \%$; ${ }^{* *}$ significant at $5 \%$; ${ }^{* * *}$ significant at $1 \%$ 


\section{Table 8. Summary of Absorption Channels}

\begin{tabular}{|c|c|c|c|c|}
\hline Explanatory variable & $\Delta \mathrm{L}(\mathrm{e}, \mathrm{r}) / \mathrm{L}(\mathrm{e}, \mathrm{r} ; 2001)$ & & & \\
\hline Dependent variable & Non-employment & Between & Within & Interaction \\
\hline \multicolumn{5}{|c|}{ OLS - All industries (16) } \\
\hline coeff. & 0.269 & 0.049 & 0.568 & 0.114 \\
\hline stdev. & {$[0.015]^{\star * *}$} & {$[0.024]^{* *}$} & {$[0.023]^{* * *}$} & {$[0.014]^{\star * *}$} \\
\hline \multicolumn{5}{|l|}{ IV - All industries (16) } \\
\hline coeff. & 0.272 & 0.034 & 0.586 & 0.108 \\
\hline stdev. & {$[0.015]^{* * *}$} & {$[0.027]$} & {$[0.025]^{* * *}$} & {$[0.019]^{* * *}$} \\
\hline \multicolumn{5}{|c|}{ OLS - All industries (30) } \\
\hline coeff. & 0.269 & 0.059 & 0.452 & 0.22 \\
\hline stdev. & {$[0.015]^{* * *}$} & {$[0.026]^{* *}$} & {$[0.040]^{* * *}$} & {$[0.053]^{* * *}$} \\
\hline \multicolumn{5}{|l|}{ IV - All industries (30) } \\
\hline coeff. & 0.272 & 0.037 & 0.408 & 0.283 \\
\hline stdev. & {$[0.015]^{\star * *}$} & {$[0.027]$} & {$[0.044]^{* * *}$} & {$[0.051]^{\star \star *}$} \\
\hline
\end{tabular}

Standard errors in brackets

* significant at $10 \%$; ${ }^{* *}$ significant at $5 \% ;{ }^{* * *}$ significant at $1 \%$

Note: Estimated under specification 5 in previous tables: Estimation with region and education fixed effects. Excluded province-education observations for Ceuta and Melilla. Robust standard errors. 
Table 9. Contribution by industry. IV estimates.

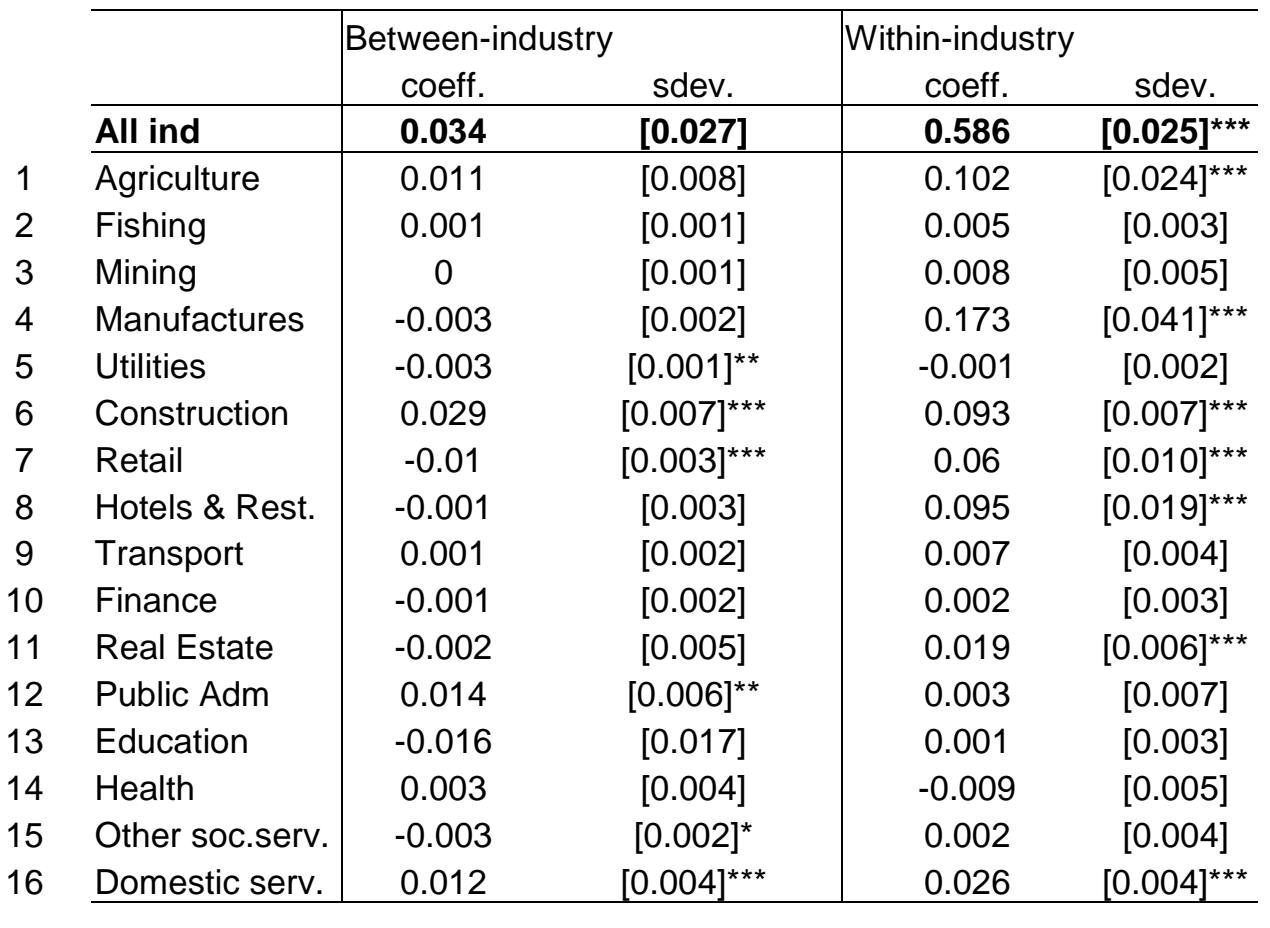

Standard errors in brackets

* significant at $10 \% ;{ }^{* *}$ significant at $5 \% ;{ }^{* * *}$ significant at $1 \%$

Note: In the left panel, the dependent variable is the weighted average of growth in total employment by industry. In the right panel, the dependent variable is the weighted average of the percentage change in the share of each education group in sectoral employment. The table reports instrumental variable estimates (with robust standard errors) in a sample that excludes outliers. We used the 16 industry classification. 
Table 10. Wages in Construction, 2001-2006. Annual salary (euros).

\begin{tabular}{|c|c|c|c||}
\hline $\begin{array}{c}\text { w (euros) } \\
\text { 2006 }\end{array}$ & Low skill & Medium skill & High skill \\
\hline min & 11769 & 12745 & 13016 \\
mean & 14219 & 16796 & 22627 \\
max & 19732 & 28317 & 40184 \\
sdev & 1753 & 2889 & 6055 \\
\hline
\end{tabular}

\begin{tabular}{|c|c|c|c||}
\hline $\begin{array}{c}\text { pch_w } \\
\text { 2001-2006 }\end{array}$ & Low skill & Medium skill & High skill \\
\hline min & 0.08 & 0.03 & 0.16 \\
mean & 0.23 & 0.23 & 0.25 \\
max & 0.35 & 0.34 & 0.64 \\
sdev & 0.03 & 0.04 & 0.13 \\
\hline
\end{tabular}

Note: Wage growth between 2002 and 2006, rescaled to a 5-year increase. Professional categories, from lowest skill/wage to highest: "Peón ordinario", "Oficial de primera administrativo", and "Titulado superior". The first two categories are on-site workers, mainly distinguished by experience. The last group are professionals with advanced university degrees.

Source: Data compilations in "Province-level remuneration in collective bargaining agreements for the construction sector," by UGT ("Unión General de Trabajadores") Technical Staff. 
Table 11. Changes in relative factor intensities and percentage changes in wages in Construction.

\begin{tabular}{lcccc}
\hline & OLS & IV & OLS & IV \\
Dep.Var. & $\Delta \lambda(e, r ;$ cons $)$ & $\Delta \lambda(e, r ;$ cons $)$ & $\% \Delta \mathrm{w}(\mathrm{e}, \mathrm{r} ;$ cons $)$ & $\% \Delta \mathrm{w}(\mathrm{e}, \mathrm{r} ;$ cons $)$ \\
\hline pch_L & 0.18 & 0.173 & -0.021 & -0.01 \\
sdev & {$[0.037]^{\star * *}$} & {$[0.038]^{\star * *}$} & {$[0.022]$} & {$[0.034]$} \\
constant & -0.054 & -0.036 & 0.225 & 0.224 \\
sdev & {$[0.018]^{* *}$} & {$[0.054]$} & {$[0.011]^{* * *}$} & {$[0.048]^{* * *}$} \\
educ2 & 0.097 & 0.101 & 0.012 & 0.006 \\
sdev & {$[0.029]^{\star * *}$} & {$[0.027]^{* * *}$} & {$[0.017]$} & {$[0.024]$} \\
educ3 & 0.032 & 0.036 & 0.036 & 0.03 \\
sdev & {$[0.027]$} & {$[0.027]$} & {$[0.019]^{*}$} & {$[0.024]$} \\
\hline obs. & 150 & 150 & 150 & 150 \\
\hline R2 & 0.64 & 0.64 & 0.45 & 0.45 \\
\hline
\end{tabular}

Note: The dependent variable in the left panel, $\Delta \lambda$ (e,r;cons), is the 2001-2006 change in the fraction of employment in Construction with education level "e". The dependent variable in the right panel is $\% \Delta \mathrm{w}(\mathrm{e}, \mathrm{r})$, the percentage change over 2001-2006 for wages of workers with skill level "e" in Construction. Estimates are based on a sample that excludes outliers. We report robust standard errors.

Table 12. Predicted values, IV estimates.

\begin{tabular}{l|c|c|c|}
\hline & Low Immig. & High Immig. & HIGH - LOW \\
\hline$\Delta L(e, r) / L(e, r, 2001)$ & & & \\
$H S D$ & -0.510 & -0.080 & 0.430 \\
$H S G$ & 0.190 & 0.280 & 0.090 \\
COG & 0.170 & 0.270 & 0.100 \\
\hline & & & \\
\hline$\lambda(e, r ; c o n s)$ & & & \\
$H S D$ & -0.124 & -0.050 & 0.074 \\
$H S G$ & 0.098 & 0.113 & 0.016 \\
COG & 0.029 & 0.047 & 0.017 \\
\hline$\% \Delta w(e, r ; c o n s)$ & & & \\
HSD & & & \\
$H S G$ & 0.229 & 0.225 & -0.004 \\
COG & 0.228 & 0.227 & -0.001 \\
\hline
\end{tabular}

Note: High-immigration provinces have above median 2001-2006 immigration, relative to 2001 total population. Low-immigration provinces have below median values. 